\title{
PENGARUH PUPUK KANDANG KAMBING DAN PUPUK ORGANIK CAIR NASA TERHADAP PERTUMBUHAN DAN HASIL TANAMAN PAKCOY (Brassica rapa L.) VARIETAS NAULI F1
}

\author{
Dedy Hidayat ${ }^{1}$, Abdul Rahmi ${ }^{2}$, Helda Syahfari ${ }^{2}$, Puji Astuti ${ }^{2}$ \\ ${ }^{1}$ Prodi Agroteknologi, Fakultas Pertanian, Universitas 17 Agustus 1945 Samarinda 75124, \\ Indonesia. Jl. Ir. H. Juanda No.80 Samarinda 75124, Indonesia. \\ ${ }^{2}$ Dosen Prodi Agroteknologi, Fakultas Pertanian, Universitas 17 Agustus 1945 Samarinda \\ 75124, Indonesia. \\ E-Mail: dedy98@gmail.com,rahmi@untag-smd.ac.id
}

\begin{abstract}
ABSTRAK
Pengaruh Pupuk Kandang Kambing dan Pupuk Organik Cair Nasa terhadap Pertumbuhan dan Hasil Tanaman Pakcoy (Brassica rapa L.) Varietas Nauli F1. Jenis sawi yang cukup populer dan banyak dikonsumsi masyarakat antara lain pakcoy dan pakcoy termasuk jenis yang banyak dibudidayakan petani saat ini.

Tujuan penelitian ini adalah untuk mengetahui pengaruh pemberian pupuk kandang kambing dan POC Nasa serta interaksi terhadap pertumbuhan dan hasil tanaman pakcoy, dan untuk mendapatkan dosis yang terbaik dari pupuk kandang kambing dan konsentrasi POC Nasa untuk menghasilkan tanaman pakcoy yang tinggi.

Penelitian menggunakan Rancangan Acak Lengkap (RAL) dalam Percobaan Faktorial 4 x 4, dengan dua faktor perlakuan yang diulang sebanyak 5 kali. Faktor pertama adalah dosis pupuk kandang kambing (K) yang terdiri atas 4 taraf yaitu : tanpa pupuk kandang kambing (k0), $5 \mathrm{Mg} \mathrm{ha}^{-1}$ atau 37,00 $\mathrm{g} \mathrm{polibag}^{-1}(\mathrm{k} 1) ; 7,5$ $\mathrm{Mg} \mathrm{ha}^{-1}$ atau 56,25 $\mathrm{g} \mathrm{polibag}^{-1}(\mathrm{k} 2)$, dan $10 \mathrm{Mg} \mathrm{ha}^{-1}$ atau 75,00 $\mathrm{g} \mathrm{polibag}^{-1}(\mathrm{k} 3)$. Faktor kedua adalah konsentrasi POC Nasa (N) yang terdiri atas 4 taraf yaitu : tanpa POC Nasa (n0), $2 \mathrm{ml} \mathrm{l}^{-1}$ air (n1), $4 \mathrm{ml} \mathrm{l}^{-1}$ air $(\mathrm{Nn})$, dan $6 \mathrm{ml}^{-1}$ air (3).

Hasil penelitian menunjukkan bahwa : Perlakuan pupuk kandang kambing berpengaruh sangat nyata terhadap tinggi tanaman dan jumlah daun pada umur 14, 21, dan 28 hari setelah tanam, dan produksi tanaman pakcoy. Perlakuan POC Nasa berpengaruh sangat nyata terhadap tinggi tanaman dan jumlah daun pada umur 14, 21, dan 28 hari setelah tanam, dan produksi tanaman pakcoy. Perlakuan interaksi antara pupuk kandang kambing dan POC Nasa berpengaruh nyata sampai berpengaruh sangat nyata terhadap tinggi tanaman dan jumlah daun pada umur 14, 21, dan 28 hari setelah tanam, dan produksi tanaman pakcoy. Produksi tanaman pakcoy yang paling tinggi dihasilkan pada perlakuan kombinasi 75,00 $\mathrm{g}^{-1}$ polibag pupuk kandang kambing dan $6 \mathrm{ml} \mathrm{l}^{-1}$ air POC Nasa $(\mathrm{k} 3 \mathrm{n} 3)$ yaitu 181,60 $\mathrm{g}^{-1}$ polibag, sedangkan yang paling rendah dihasilkan pada kombinasi tanpa pupuk kandang kambing dan tanpa POC Nasa (k0n0) yaitu 26,60 $\mathrm{g}^{-1}$ polibag.
\end{abstract}

Kata kunci : Pakcoy, Pupuk Kandang, Pupuk Organik.

\section{ABSTRACT}

Effect of Goat Manure Fertilizer and Nasa Liquid Organic Fertilizer on the Growth and Yield of Box Choy (Brassica rapa L.) Nauli F1 Variety. Types of mustard greens that are quite popular and widely consumed by the community include Pakcoy and Pakcoy, including the type that is widely cultivated by farmers today.

The purpose of this research is to study the effect of goat manure fertilizer and Nasa liquid organic fertilizer (POC Nasa) and its interaction on the growth and yield of box choy and also to find the proper dosage of compost fertilizer and POC Nasa concentration for obtaining the best growth and yield of box choy.

The research used Completely Randomized Design (CRD) in $4 \times 4$ Factorial Experiment and five replications. The first factor was the dosage of goat manure fertilizer $(K)$ consisting of 4 levels : without goat manure fertilizer application ( $k 0), 37,00 \mathrm{~g}$ polybag $^{-1}(\mathrm{kl}), 56,25 \mathrm{~g} \mathrm{polybag}^{-1}(\mathrm{k} 2)$; and 75,00 $\mathrm{g} \mathrm{polybag}^{-1}$ (k3). The second factor was the concentration of POC Nasa (D) consisting 4 levels : without POC Nasa application (nO), $2 \mathrm{ml} \mathrm{l}^{-1}$ water (n1), $4 \mathrm{ml} \mathrm{l}^{-1}$ water (n2), and $6 \mathrm{ml} \mathrm{l}^{-1}$ water (n3). 
The results of experiment showed that: the goat manure fertilizer treatment affected very significantly on the plant lenght and number of leaves at age 14, 21, and 28 days after planting, and yied of box choy; the POC Nasa treatment affected very significantly on the plant lenght and number of leaves at age 14, 21, and 28 days after planting, and yied of box choy; the interaction treatment between goat manure fertilizer and POC Nasa affected significantly until very significantly on the the plant lenght and number of leaves at age 14, 21, and 28 days after planting, and yied of box choy; and The highest production was produced at combination treatment of 75,00 $\mathrm{g}^{-1}$ polybag of goat manure and $6 \mathrm{ml} \mathrm{l}^{-1}$ water POC Nasa treatment $(\mathrm{k} 3 \mathrm{n} 3)$ of 181,60 $\mathrm{g}$ polybag ${ }^{-1}$, while the lowest is produced in the combination without goat manure fertilizer and without POC Nasa (k0nO) of 26,60 $\mathrm{g}^{-1}$ polybag.

Key words : Manure, Organic Fertilizer, Pakcoy.

\section{PENDAHULUAN}

Sawi adalah salah satu jenis tanaman sayuran yang mudah dibudidayakan, sayuran berdaun hijau ini termasuk tanaman yang tahan terhadap hujan, dan dapat dipanen sepanjang tahun tidak tergantung dengan musim. Sayuran sawi juga banyak diminati dan digemari masyarakat karena rasanya yang enak. Sawi merupakan tanaman sayuran berumur pendek yaitu pada umur 45 hari setelah tanam sudah dapat dipanen (Edi dan Bobihoe, 2010).

Beberapa jenis sawi yang saat ini cukup popular dan banyak dikonsumsi masyarakat antara lain sawi hijau, sawi putih dan pakcoy. Dari ketiga jenis sawi tersebut, pakcoy termasuk jenis yang banyak dibudidayakan petani saat ini. Batang dan daunnya yang lebih lebar dari sawi hijau biasa, membuat sawi jenis ini lebih sering digunakan masyarakat dalam berbagai menu masakan. Hal ini memberikan prospek bisnis yang cukup cerah bagi para petani pakcoy karena budidayanya mudah dan permintaan pasarnya cukup tinggi. Tahapan budidaya pakcoy di dataran tinggi dan di dataran rendah juga tidak terlalu berbeda yaitu meliputi penyiapan benih, pengolahan lahan, teknik penanaman, penyediaan pupuk dan pestisida, serta proses pemeliharaan tanaman (Sukmawati, 2012).

Pertumbuhan tanaman dipengaruhi oleh jenis pupuk yang digunakan, penggunaan pupuk kimia/anorganik menyebabkan pertumbuhan yang maksimal dan cepat, tetapi penggunaan pupuk kimia/anorgaik ini secara berlebihan akan mempengaruhi kesuburan tanah dan kesehatan manusia, sehingga akan lebih baik apabila pemupukan tanaman menggunakan pupuk yang ramah lingkungan seperti pupuk organik yang terbuat dari bahanbahan organik (Dewi dkk, 2013).

Teknik usaha tani yang dilakukan saat ini banyak bergantung pada penggunaan bahan anorganik seperti pupuk dan pestisida kimia. Keadaan ini dalam jangka waktu lama akan berdampak negatif terhadap kelestarian lingkungan, seperti produktivitas lahan sulit ditingkatkan dan bahkan cenderung menurun (Sugito, et al., 1995). Upaya mengatasi permasalahan yang ditimbulkan oleh pengaruh negatif di atas, sudah ada teknologi tepat guna yang aman bagi kelangsungan tanah di kemudian hari yaitu dengan menggunakan bahan-bahan organik seperti membuat pupuk organik dan pestisida organik.

Kotoran ternak memiliki kandungan sejumlah unsur hara yang diperlukan oleh tanaman dan mempunyai kemampuan untuk memperbaiki sifat fisik tanah. Kotoran ternak berpotensi sebagai bahan baku pupuk organik karena kotoran ternak memiliki unsur hara yang dibutuhkan oleh tanah misalnya populasi kambing yaitu mencapai 2 juta ekor dan dalam sehari kotoran yang dikeluarkan oleh kambing sebanyak $4 \mathrm{~kg}$ (Disnak 
Jatim, 2011) sehingga dalam sehari akan dihasilkan 8 juta kg kotoran kambing. Dengan jumlah kotoran ternak yang sangat tinggi tersebut perlu dimanfaatkan lebih lanjut agar tidak terbuang sia-sia misalnya sebagai bahan baku pupuk organik. Pupuk kandang kambing mengandung bahan organik yang dapat menyediakan unsur hara bagi tanaman melalui proses dekomposisi. Proses ini terjadi secara bertahap dengan melepaskan bahan organik yang sederhana untuk pertumbuhan tanaman.

POC Nasa merupakan pupuk yang berbentuk cair, pupuk ini mudah disiapkan dan sangat berguna untuk banyak hal, termasuk pembenihan, tumbuhan kecil, tanaman buah-buahan dan tanam-tanaman besar lainnya. Ini merupakan suatu cara yang baik untuk membuat pupuk yang kaya akan unsur hara dari pupuk bahan-bahan organik lainnya dalam jumlah kecil.

POC Nasa dapat dengan mudah disiramkan pada lahan-lahan yang luas. POC Nasa dibuat dalam larutan konsentrasi sehingga perlu dicampur dengan air untuk pemakaiannya. Pupuk dapat disimpan dan bertahan lama dan bisa digunakan untuk areal yang lebih luas. Pupuk dapat disimpan dimana saja, asalkan terlindung dari matahari dan hujan lebat.

Berdasarkan uraian diatas, maka dilakukan penelitian mengenai pengaruh pemberian pupuk kandang kambing dan POC Nasa serta interaksinya terhadap pertumbuhan dan hasil tanaman pakcoy (Brassica rapa L.) varietas Nauli F1. Tujuan penelitian adalah untuk mengetahui pengaruh pemberian pupuk kandang kambing dan POC Nasa serta interaksi terhadap pertumbuhan dan hasil tanaman pakcoy. Untuk mendapatkan dosis yang terbaik dari pupuk kandang kambing dan konsentrasi POC Nasa untuk menghasilkan tanaman pakcoy yang tinggi.

\section{METODA PENELITIAN}

\subsection{Tempat dan Waktu}

Penelitian bertempat di Desa Benua Harapan/SP-1, Kecamatan Batu Ampar, Kabupaten Kutai Timur, Provinsi Kalimantan Timur. Pada bulan Pebruari-Maret 2019.

\subsection{Bahan dan Alat}

Bahan yang digunakan dalam penelitian ini adalah pupuk kandang kambing, POC NASA, kompos, dan benih Pakcoy varietas Nauli F1.

Alat yang digunakan dalam penelitian ini adalah bak semai, cangkul, parang, meteran, tugal kayu, solet bambu, gembor, tali rafia, paranet, kertas label, polibag, spit, hand sprayer, meteran, timbangan analitik, pisau, alat tulis dan kamera.

\subsection{Rancangan Penelitian}

Penelitian menggunakan Rancangan Acak Lengkap (RAL) dalam Percobaan Faktorial 4 x 4, dengan dua faktor perlakuan yang diulang sebanyak 5 kali. Faktor-faktor perlakuan yaitu sebagai berikut :

Faktor dosis pupuk kandang kambing $(\mathrm{K})$ yang terdiri atas 4 taraf yaitu :

$\mathrm{k} 0=$ tanpa pupuk kandang kambing

$$
\begin{aligned}
& \mathrm{k} 1=\underset{\text { dosis } 5 \mathrm{Mg} \mathrm{ha}^{-1} \text { atau 37,00 } \mathrm{g}}{\text { polibag }} \\
& \mathrm{k} 2=\underset{\text { dosis } 7,5 \mathrm{Mg} \mathrm{ha}^{-1} \text { atau } 56,25}{\mathrm{~g} \text { polibag }} \\
& \mathrm{k} 3={\operatorname{dosis~} 10 \mathrm{Mg} \mathrm{ha}^{-1} \text { atau } 75,00 \mathrm{~g}}_{\text {polibag }^{-1}}
\end{aligned}
$$

Faktor konsentrasi POC Nasa (N) yang terdiri atas 4 taraf yaitu :

n0 = tanpa POC Nasa

$\mathrm{n} 1=$ konsentrasi $2 \mathrm{ml} \mathrm{l}^{-1}$ air

$\mathrm{n} 2=$ konsentrasi $4 \mathrm{ml} \mathrm{l}^{-1}$ air

$\mathrm{n} 3=$ konsentrasi $6 \mathrm{ml}^{-1}$ air 
sehingga diperoleh kombinasi perlakuan sebanyak 4 x 4 kombinasi yaitu

seperti disajikan pada Tabel 1.

Tabel 1. Kombinasi perlakuan pupuk kandang kambing (K) dan POC Nasa (N).

\begin{tabular}{ccccc}
\hline Perlakuan Pupuk Kandang Kambing & \multicolumn{4}{c}{ Perlakuan POC Nasa (N) } \\
\cline { 2 - 5 }$(\mathrm{K})$ & $\mathrm{n} 0$ & $\mathrm{n} 1$ & $\mathrm{n} 2$ & $\mathrm{n} 3$ \\
\hline $\mathrm{k} 0$ & $\mathrm{k} 0 \mathrm{n} 0$ & $\mathrm{k} 0 \mathrm{n} 1$ & $\mathrm{k} 0 \mathrm{n} 2$ & $\mathrm{k} 0 \mathrm{n} 3$ \\
$\mathrm{k} 1$ & $\mathrm{k} 1 \mathrm{n} 0$ & $\mathrm{k} 1 \mathrm{n} 1$ & $\mathrm{k} 1 \mathrm{n} 2$ & $\mathrm{k} 1 \mathrm{n} 3$ \\
$\mathrm{k} 2$ & $\mathrm{k} 2 \mathrm{n} 0$ & $\mathrm{k} 2 \mathrm{n} 1$ & $\mathrm{k} 2 \mathrm{n} 2$ & $\mathrm{k} 2 \mathrm{n} 3$ \\
$\mathrm{k} 3$ & $\mathrm{k} 3 \mathrm{n} 0$ & $\mathrm{k} 3 \mathrm{n} 1$ & $\mathrm{k} 3 \mathrm{n} 2$ & $\mathrm{k} 3 \mathrm{n} 3$ \\
\hline
\end{tabular}

\subsection{Prosedur Penelitian \\ Persiapan media tanam}

Tanah yang digunakan menjadi media tanam adalah tanah lapisan atas kedalaman 0-20 cm yang diambil dari sekitar lokasi penelitian, setelah itu dibersihkan dari kotoran-kotoran dan dikeringanginkan sambil digemburkan selama 2 hari, kemudian dimasukkan kedalam polibag ukuran $20 \mathrm{~cm}$ dan setiap polibag diberi label kode perlakuan. Selanjutnya polibag disusun rapi sesuai hasil pengacakan dengan jarak $40 \mathrm{~cm} \mathrm{x}$ $40 \mathrm{~cm}$.

\section{Pemberian pupuk kandang kambing}

Pemberian pupuk kandang kambing pada masing-masing polibag dilakukan sesuai dengan perlakuan yaitu tanpa pupuk kandang kambing (k0); 37,00 g polibag $^{-1}(\mathrm{k} 1) ; 56,250 \mathrm{~g}_{\text {polibag }}^{-1}(\mathrm{k} 2)$; dan 75,00 g polibag ${ }^{-1}$ (k3). Pupuk kandang kambing diberikan 2 minggu sebelum tanam dengan cara menabur pupuk kandang kambing pada media tanam lalu dicampur/diaduk merata dengan tanah.

\section{Penyemaian}

Benih pakcoy ditanam dalam bak penyemaian, media semai setebal $\pm 7 \mathrm{~cm}$ yang dibuat dari campuran kompos dan tanah yang telah diayak dengan perbandingan $1: 1$. Setelah media siap, dibuat lubang tanam sedalam $\pm 1 \mathrm{~cm}$ dan setiap lubang dapat diisi dengan 1 benih pakcoy. Persemaian pakcoy membutuhkan waktu selama 2 minggu (tinggi semai $\pm 10 \mathrm{~cm}$ dan memiliki daun 2 helai), setelah itu bibit dapat dipindahkan ke polibag (satuan penelitian) yang telah disiapkan.

\section{Penanaman}

Sebelum penanaman, media tanam dalam polibag dibuat lubang tanam sedalam $\pm 5 \mathrm{~cm}$, kemudian bibit diambil dari persemaian secara hati-hati dengan menggunakan solet (bambu yang diruncingkan) agar akarnya tidak terputus, lalu ditanam dalam lubang yang telah disediakan di polibag. Setelah bibit ditanam, lubang tanam diisi dengan tanah halus sambil ditekan secara perlahanlahan agar bibit berdiri dengan tegak.

\section{Pemberian POC Nasa}

Pemberian POC Nasa pada masingmasing polibag dilakukan sesuai dengan perlakuan yaitu : tanpa POC Nasa (n0), 2 $\mathrm{ml} \mathrm{l}^{-1}$ air (n1), $4 \mathrm{ml} \mathrm{l}^{-1}$ air (n2), dan $6 \mathrm{ml} \mathrm{l}$ ${ }^{1}$ air (n3). POC Nasa diberikan dengan cara menyemprotkan langsung ke daun tanaman pakcoy, penyemprotan POC Nasa dilakukan pagi hari antara jam 08.30-09.30 Wita. Waktu penyemprotan yaitu pada saat tanaman berumur 1, 2, dan 3 minggu setelah tanam.

\section{Pemeliharaan tanaman}

Pemeliharaan adalah hal yang penting. Sehingga akan sangat berpengaruh terhadap hasil yang akan 
didapat. Pertama-tama yang perlu diperhatikan adalah:

a. Penyiraman

Penyiraman dilakukan satu kali sehari (pada pagi hari), bila turun hujan atau media tanam masih terlihat lembab maka penyiraman tidak dilakukan.

b. Penyiangan dan pembumbunan

Penyiangan dilakukan pada saat tanaman berumur 1 dan 2 minggu setelah tanam (disesuaikan dengan kondisi keberadaan gulma pada polibag penanaman) dan setelah itu dilakukan pembumbunan.

\section{Pemanenan}

Tanaman yang siap dipanen adalah tanaman daun sawi dewasa berbentuk oval melebar, tangkai daunnya berwarna hijau cerah, dan bentuknya relatif pendek. Pemanenan dilakukan setelah tanaman pakcoy berumur kurang lebih 28 hari setelah tanam dengan cara memotong bagian pangkal batang dengan pisau.

\subsection{Parameter Pengamatan}

Tinggi tanaman $(\mathrm{cm})$

Tinggi tanaman diukur pada umur 14, 21, dan 28 hari setelah tanam dengan cara mengukur dari pangkal akar sampai ujung tunas daun, dengan menggunakan penggaris/meteran.

Jumlah daun (helai)
Jumlah daun tanaman dihitung pada umur 14, 21, dan 28 hari setelah tanam dengan cara menghitung daun yang terbentuk dan telah membuka sempurna.

\section{Produksi tanaman $(\mathrm{g})$}

Menimbang berat pakcoy tiap perlakuan yaitu tanaman pakcoy selain akar.

\subsection{Analisis Data}

Untuk mengetahui pengaruh pemberian pupuk kandang kambing dan POC Nasa serta interaksinya terhadap pertumbuhan dan hasil tanaman pakcoy dilakukan dengan menganalisis data dengan sidik ragam. Model sidik ragam yang digunakan menurut Yitnosumarto (1993)

Bila hasil sidik ragam terhadap perlakuan berpengaruh tidak nyata (non signifikan) yang menunjukan F.Hitung $\leq$ F. Tabel 5\% maka tidak dilakukan uji lanjutan, tetapi bila hasil sidik ragam terhadap perlakuan berpengaruh nyata (signifikan) yang menunjukan F. Hitung $>$ F. Tabel 5\% atau berpengaruh sangat nyata yang menunjukan $F$. Hitung $>F$. Tabel 1\%, maka untuk membandingkan dua rata-rata perlakuan, dilakukan dengan uji Beda Nyata Terkecil (BNT) taraf 5\%. Rumus Umum Uji BNT disajikan sebagai berikut :

Keterangan :

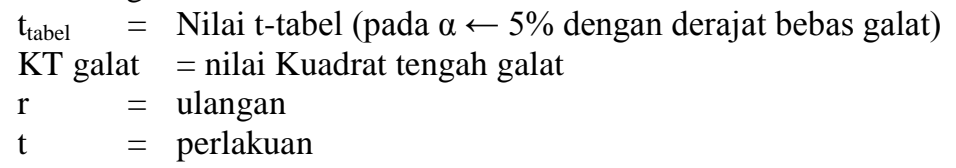

3. HASIL PENELITIAN DAN PEMBAHASAN

\subsection{Tinggi tanaman pada umur 14 hari setelah tanam}

Hasil sidik ragam menunjukkan bahwa perlakuan pupuk kandang kambing (K) dan POC Nasa (N) serta interaksinya $(\mathrm{K} \times \mathrm{N})$ berpengaruh sangat 
nyata terhadap tinggi tanaman pakcoy pada umur 14 hari setelah tanam.

Hasil penelitian pengaruh pupuk kandang kambing (K) dan POC Nasa (N) serta interaksinya $(\mathrm{K} \times \mathrm{N})$ terhadap ratarata tinggi tanaman pakcoy pada umur 14 hari setelah tanam disajikan pada Tabel 2.

Tabel 2. Rata-rata Tinggi Tanaman Pakcoy pada Umur 14 Hari Setelah Tanam pada Berbagai Dosis Pupuk Kandang Kambing dan Konsentrasi POC Nasa serta Interaksinya $(\mathrm{cm})$

\begin{tabular}{lccccc}
\hline $\begin{array}{l}\text { Faktor Pupuk } \\
\text { Kandang Kambing } \\
(\mathrm{K})\end{array}$ & $\begin{array}{c}\text { Tanpa POC } \\
\text { Nasa (n0) }\end{array}$ & $\begin{array}{c}2 \mathrm{ml} \mathrm{l}^{-1} \text { air } \\
(\mathrm{n} 1)\end{array}$ & $\begin{array}{c}4 \mathrm{ml} \mathrm{l}^{-1} \text { air } \\
(\mathrm{n} 2)\end{array}$ & $6 \mathrm{ml} \mathrm{l}^{-1}$ air $(\mathrm{n} 3)$ & $\begin{array}{c}\text { Rata-rata } \\
\text { Perlakuan } \\
(\mathrm{K}) *\end{array}$ \\
\hline $\begin{array}{l}\text { Tanpa } \\
\begin{array}{l}\text { Pukan Kambing } \\
(\mathrm{k} 0)\end{array}\end{array}$ & $11,04 \mathrm{~g}$ & $11,14 \mathrm{~g}$ & $10,90 \mathrm{~g}$ & $10,92 \mathrm{~g}$ & $11,00 \mathrm{c}$ \\
$\begin{array}{l}37,00 \mathrm{~g} \mathrm{polibag}^{-1} \\
(\mathrm{k} 1)\end{array}$ & $12,38 \mathrm{f}$ & $12,76 \mathrm{ef}$ & $13,32 \mathrm{~cd}$ & $13,70 \mathrm{c}$ & $13,04 \mathrm{~b}$ \\
$\begin{array}{l}56,25 \text { g polibag }^{-1} \\
(\mathrm{k} 2)\end{array}$ & $12,50 \mathrm{ef}$ & $12,60 \mathrm{ef}$ & $13,52 \mathrm{c}$ & $12,98 \mathrm{de}$ & $12,90 \mathrm{~b}$ \\
$\begin{array}{l}75,00 \text { g polibag }^{-1} \\
(\mathrm{k} 3)\end{array}$ & $13,58 \mathrm{c}$ & $14,28 \mathrm{~b}$ & $15,30 \mathrm{a}$ & $14,44 \mathrm{~b}$ & $14,40 \mathrm{a}$ \\
\hline $\begin{array}{l}\text { Rata-rata Perlakuan } \\
(\mathrm{N}) *\end{array}$ & $12,38 \mathrm{~d}$ & $12,70 \mathrm{c}$ & $13,26 \mathrm{a}$ & $13,01 \mathrm{~b}$ & \\
\hline
\end{tabular}

*) Angka rata-rata yang diikuti dengan huruf sama adalah berbeda tidak nyata berdasarkan hasil uji BNT taraf 5\%. (Nilai BNT K =0,23; BNT N =0,23, dan BNT KxN =0,48).

Hasil uji BNT taraf 5\% pengaruh pupuk kandang kambing (K) terhadap rata-rata tinggi tanaman pakcoy pada umur 14 hari setelah tanam menunjukkan bahwa perlakuan $75,00 \mathrm{~g}_{\text {polibag }}{ }^{-1}(\mathrm{k} 3)$ berbeda nyata dibandingkan dengan perlakuan tanpa pupuk kandang kambing (k0), 37,00 g polibag $^{-1}$ (k1); dan 56,25 g polibag $^{-1}(\mathrm{k} 2)$. Perlakuan $37,00 \mathrm{~g}$ polibag $^{-1}(\mathrm{k} 1)$ dan $56,25 \mathrm{~g}$ polibag $^{-1}(\mathrm{k} 2)$ berbeda nyata dibandingkan dengan perlakuan tanpa pupuk kandang kambing (k0), tetapi diantara kedua perlakuan $(\mathrm{k} 1$ dan k2) tersebut berbeda tidak nyata. Tanaman pakcoy paling tinggi pada umur 14 hari setelah tanam dhasilkan pada perlakuan $75,00 \mathrm{~g} \mathrm{polibag}^{-1}(\mathrm{k} 3)$ yaitu $14,40 \mathrm{~cm}$, sedangkan yang paling rendah dihasilkan pada perlakuan tanpa pupuk kandang kambing (k0) yaitu $11,00 \mathrm{~cm}$ (Tabel 2).

Hasil uji BNT taraf 5\% pengaruh POC Nasa $(\mathrm{N})$ terhadap rata-rata tinggi tanaman pakcoy pada umur 14 hari setelah tanam menunjukkan bahwa perlakuan $2 \mathrm{ml} \mathrm{l}^{-1}$ air (n1); $4 \mathrm{ml} \mathrm{l}^{-1}$ air (n2); dan $6 \mathrm{ml} \mathrm{l}^{-1}$ air (n3) berbeda nyata dibandingkan dengan perlakuan tanpa POC Nasa (n0), dan diantara ketiga perlakuan $(\mathrm{n} 1, \mathrm{n} 2$, dan $\mathrm{n} 3)$ tersebut juga berbeda nyata. Tanaman pakcoy paling tinggi pada umur 14 hari setelah tanam dhasilkan pada perlakuan $4 \mathrm{ml} \mathrm{l}^{-1}$ air (n3) yaitu $13,26 \mathrm{~cm}$, sedangkan yang paling rendah dihasilkan pada perlakuan tanpa POC Nasa (n0) yaitu $12,38 \mathrm{~cm}$ (Tabel 2).

Hasil uji BNT taraf 5\% pengaruh interaksi antara perlakuan pupuk kandang kambing dan POC Nasa $(\mathrm{KxN})$ terhadap rata-rata tinggi tanaman pakcoy pada umur 14 hari setelah tanam menunjukkan bahwa kombinasi $\mathrm{k} 3 \mathrm{n} 2$ berbeda nyata dibandingkan dengan kombinasi k0n0, k0n1, k0n2, k0n3, k1n0, k1n1, k1n2, $\mathrm{k} 1 \mathrm{n} 3, \mathrm{k} 2 \mathrm{n} 0, \mathrm{k} 2 \mathrm{n} 1, \mathrm{k} 2 \mathrm{n} 2 \mathrm{~m} \mathrm{k} 2 \mathrm{n} 3, \mathrm{k} 3 \mathrm{n} 0$, $\mathrm{k} 3 \mathrm{n} 1$, dan k3n3. Kombinasi k3n1 dan $\mathrm{k} 3 \mathrm{n} 3$ berbeda nyata dibandingkan dengan kombinasi k0n0, k0n1, k0n2, k0n3, k1n0, $\mathrm{k} 1 \mathrm{n} 1, \mathrm{k} 1 \mathrm{n} 2, \mathrm{k} 1 \mathrm{n} 3, \mathrm{k} 2 \mathrm{n} 0, \mathrm{k} 2 \mathrm{n} 1, \mathrm{k} 2 \mathrm{n} 2$, k2n3, dan k3n0. Kombinasi k1n3, k2n2, dan $\mathrm{k} 3 \mathrm{n} 0$ berbeda nyata dibandingkan dengan kombinasi k0n0, k0n1, k0n2, 
k0n3, k1n0, k1n1, k2n0, k2n1, dan k2n3, tetapi berbeda tidak nyata dibandingkan dengan kombinasi k1n2. Kombinasi $\mathrm{k} 1 \mathrm{n} 2$ berbeda nyata dibandingkan dengan kombinasi k0n0, k0n1, k0n2, k0n3, k1n0, $\mathrm{k} 1 \mathrm{n} 1$, k2n0, dan $\mathrm{k} 2 \mathrm{n} 1$, tetapi berbeda tidak nyata dibandingkan dengan kombinasi k2n3. Kombinasi k2n3 berbeda nyata dibandingkan dengan kombinasi k0n0, k0n1, k0n2, k0n3, dan $\mathrm{k} 1 \mathrm{n} 0$, tetapi berbeda tidak nyata dibandingkan dengan kombinasi k1n1, k2n0, dan k2n1. Kombinasi k1n1, k2n0, dan $\mathrm{k} 2 \mathrm{n} 1$ berbeda nyata dibandingkan dengan kombinasi k0n0, k0n1, k0n2, dan k0n3, tetapi berbeda tidak nyata dibandingkan dengan kombinasi k1n0. Kombinasi k1n0 berbeda nyata dibandingkan dengan kombinasi k0n0, k0n1, k0n2, dan k0n3. Kombinasi k0n1, k0n2 dan k0n3 berbeda nyata tidak dibandingkan dengan kombinasi k0n0. Tanaman pakcoy paling tinggi pada umur 14 hari setelah tanam dhasilkan pada kombinasi k3n2 yaitu 15,30 cm, sedangkan yang paling rendah dihasilkan pada kombinasi k0n0 yaitu $11,04 \mathrm{~cm}$ (Tabel 2).

\subsection{Tinggi tanaman pada umur 21 hari setelah tanam}

Hasil sidik ragam menunjukkan bahwa perlakuan pupuk kandang kambing (K) dan POC Nasa (N) serta interaksinya $(\mathrm{K} \times \mathrm{N})$ berpengaruh sangat nyata terhadap tinggi tanaman pakcoy pada umur 21 hari setelah tanam.

Hasil penelitian pengaruh pupuk kandang kambing (K) dan POC Nasa (N) serta interaksinya $(\mathrm{K} \times \mathrm{N})$ terhadap ratarata tinggi tanaman pakcoy pada umur 21 hari setelah tanam disajikan pada Tabel 3.

Tabel 3. Rata-rata Tinggi Tanaman Pakcoy pada Umur 21 Hari Setelah Tanam pada Berbagai Dosis Pupuk Kandang Kambing dan Konsentrasi POC Nasa serta Interaksinya (cm)

\begin{tabular}{lccccc}
\hline $\begin{array}{l}\text { Faktor Pupuk } \\
\text { Kandang Kambing } \\
(\mathrm{K})\end{array}$ & $\begin{array}{c}\text { Tanpa POC } \\
\text { Nasa }(\mathrm{n} 0)\end{array}$ & $\begin{array}{c}2 \mathrm{ml} \mathrm{l} \text {-1 } \\
(\mathrm{n} 1)\end{array}$ & $\begin{array}{c}4 \mathrm{ml} \mathrm{l}^{-1} \text { air } \\
(\mathrm{n} 2)\end{array}$ & $6 \mathrm{ml} \mathrm{l}^{-1}$ air $(\mathrm{n} 3)$ & $\begin{array}{c}\text { Rata-rata } \\
\text { Perlakuan } \\
(\mathrm{K})^{*}\end{array}$ \\
\hline $\begin{array}{l}\text { Tanpa } \\
\begin{array}{l}\text { Pukan Kambing } \\
(\mathrm{k} 0)\end{array}\end{array}$ & $12,98 \mathrm{gh}$ & $13,16 \mathrm{gh}$ & $12,94 \mathrm{gh}$ & $12,72 \mathrm{~h}$ & $12,95 \mathrm{c}$ \\
$\begin{array}{l}37,00 \text { g polibag }^{-1} \\
(\mathrm{k} 1)\end{array}$ & $13,79 \mathrm{fg}$ & $14,30 \mathrm{ef}$ & $15,24 \mathrm{~cd}$ & $14,80 \mathrm{de}$ & $14,51 \mathrm{~b}$ \\
$\begin{array}{l}56,25 \text { g polibag }^{-1} \\
(\mathrm{k} 2)\end{array}$ & $14,06 \mathrm{ef}$ & $14,04 \mathrm{ef}$ & $14,76 \mathrm{de}$ & $15,24 \mathrm{c}$ & $14,53 \mathrm{~b}$ \\
$\begin{array}{l}75,00 \text { g polibag }^{-1} \\
(\mathrm{k} 3)\end{array}$ & $15,20 \mathrm{~cd}$ & $15,98 \mathrm{bc}$ & $17,16 \mathrm{a}$ & $16,66 \mathrm{ab}$ & $16,25 \mathrm{a}$ \\
\hline $\begin{array}{l}\text { Rata-rata Perlakuan } \\
(\mathrm{N}) *\end{array}$ & $13,99 \mathrm{c}$ & $14,37 \mathrm{~b}$ & $15,03 \mathrm{a}$ & $14,86 \mathrm{a}$ & \\
\hline
\end{tabular}

*) Angka rata-rata yang diikuti dengan huruf sama adalah berbeda tidak nyata berdasarkan hasil uji BNT taraf 5\%. (Nilai BNT K =0,39; BNT N =0,39, dan BNT KxN = 0,78).

Hasil uji BNT taraf 5\% pengaruh pupuk kandang kambing (K) terhadap rata-rata tinggi tanaman pakcoy pada umur 21 hari setelah tanam menunjukkan bahwa perlakuan 75,00 $\mathrm{g}_{\text {polibag }}{ }^{-1}(\mathrm{k} 3)$ berbeda nyata dibandingkan dengan perlakuan tanpa pupuk kandang kambing (k0); 37,00 $\mathrm{g}$ polibag $^{-1}(\mathrm{k} 1)$; dan 56,25 g polibag $^{-1}$ (k2). Perlakuan $37,00 \quad \mathrm{~g}$ polibag $^{-1}(\mathrm{k} 1)$ dan $56,25 \mathrm{~g} \mathrm{polibag}^{-1}(\mathrm{k} 2)$ berbeda nyata dibandingkan dengan perlakuan tanpa pupuk kandang kambing $(\mathrm{k} 0)$, tetapi diantara kedua perlakuan $(\mathrm{k} 1$ dan k2) tersebut berbeda tidak nyata. Tanaman pakcoy paling tinggi pada umur 21 hari setelah tanam dhasilkan pada perlakuan $75,00 \mathrm{~g} \mathrm{polibag}^{-1}(\mathrm{k} 3)$ yaitu $16,25 \mathrm{~cm}$, sedangkan yang paling rendah 
dihasilkan pada perlakuan tanpa pupuk kandang kambing (k0) yaitu $12,95 \mathrm{~cm}$ (Tabel 3).

Hasil uji BNT taraf 5\% pengaruh POC Nasa $(\mathrm{N})$ terhadap rata-rata tinggi tanaman pakcoy pada umur 21 hari setelah tanam menunjukkan bahwa $4 \mathrm{ml} \mathrm{l}^{-}$ ${ }^{1}$ air (n2) dan $6 \mathrm{ml} \mathrm{l}^{-1}$ air (n3) berbeda nyata dibandingkan dengan perlakuan tanpa POC Nasa (n0) dan perlakuan $2 \mathrm{ml}$ $1^{-1}$ air (n1), tetapi diantara kedua perlakuan (n2 dan n3) tersebut berbeda tidak nyata. Perlakuan $2 \mathrm{ml} \mathrm{l}^{-1}$ air (n1) berbeda nyata dibandingkan dengan perlakuan tanpa POC Nasa (n0). Tanaman pakcoy paling tinggi pada umur 21 hari setelah tanam dhasilkan pada perlakuan $4 \mathrm{ml} \mathrm{l}^{-1}$ air (n3) yaitu $15,03 \mathrm{~cm}$, sedangkan yang paling rendah dihasilkan pada perlakuan tanpa POC Nasa (n0) yaitu 13,99 cm (Tabel 3).

Hasil uji BNT taraf 5\% pengaruh interaksi antara perlakuan pupuk kandang kambing dan POC Nasa $(\mathrm{KxN})$ terhadap rata-rata tinggi tanaman pakcoy pada umur 21 hari setelah tanam menunjukkan bahwa kombinasi $\mathrm{k} 3 \mathrm{n} 2$ berbeda nyata dibandingkan dengan kombinasi k0n0, $\mathrm{k} 0 \mathrm{n} 1, \mathrm{k} 0 \mathrm{n} 2, \mathrm{k} 0 \mathrm{n} 3, \mathrm{k} 1 \mathrm{n} 0, \mathrm{k} 1 \mathrm{n} 1, \mathrm{k} 1 \mathrm{n} 2$, $\mathrm{k} 1 \mathrm{n} 3, \mathrm{k} 2 \mathrm{n} 0, \mathrm{k} 2 \mathrm{n} 1, \mathrm{k} 2 \mathrm{n} 2, \mathrm{k} 2 \mathrm{n} 3, \mathrm{k} 3 \mathrm{n} 0$, dan $\mathrm{k} 3 \mathrm{n} 1$, tetapi berbeda tidak nyata dibandingkan dengan kombinasi k3n3. Kombinasi k3n3 berbeda nyata dibandingkan dengan kombinasi k0n0, $\mathrm{k} 0 \mathrm{n} 1, \mathrm{k} 0 \mathrm{n} 2, \mathrm{k} 0 \mathrm{n} 3, \mathrm{k} 1 \mathrm{n} 0, \mathrm{k} 1 \mathrm{n} 1, \mathrm{k} 1 \mathrm{n} 2$, $\mathrm{k} 1 \mathrm{n} 3, \mathrm{k} 2 \mathrm{n} 0, \mathrm{k} 2 \mathrm{n} 1, \mathrm{k} 2 \mathrm{n} 2, \mathrm{k} 2 \mathrm{n} 3$, dan k3n0, tetapi berbeda tidak nyata dibandingkan dengan kombinasi k3n1. Kombinasi k3n1 berbeda nyata dibandingkan dengan kombinasi k0n0, k0n1, k0n2, k0n3, k1n0, $\mathrm{k} 1 \mathrm{n} 1, \mathrm{k} 1 \mathrm{n} 3, \mathrm{k} 2 \mathrm{n} 0, \mathrm{k} 2 \mathrm{n} 1$, dan $\mathrm{k} 2 \mathrm{n} 2$, tetapi berbeda tidak nyata dibandingkan dengan kombinasi k1n2, k2n3, dan k3n0. Kombinasi k2n3 berbeda nyata dibandingkan dengan kombinasi k0n0, $\mathrm{k} 0 \mathrm{n} 1, \mathrm{k} 0 \mathrm{n} 2, \mathrm{k} 0 \mathrm{n} 3, \mathrm{k} 1 \mathrm{n} 0, \mathrm{k} 1 \mathrm{n} 1, \mathrm{k} 1 \mathrm{n} 3$, $\mathrm{k} 2 \mathrm{n} 0, \mathrm{k} 2 \mathrm{n} 1$, dan $\mathrm{k} 2 \mathrm{n} 2$, tetapi berbeda tidak nyata dibandingkan dengan kombinasi k1n2, dan k3n0. Kombinasi $\mathrm{k} 1 \mathrm{n} 2$ dan $\mathrm{k} 3 \mathrm{n} 0$ berbeda nyata dibandingkan dengan kombinasi k0n0, k0n1, k0n2, k0n3, k1n0, k1n1, k2n0, dan $\mathrm{k} 2 \mathrm{n} 1$, tetapi berbeda tidak nyata dibandingkan dengan kombinasi k1n3 dan k2n2. Kombinasi k1n3 dan k2n2 berbeda nyata dibandingkan dengan kombinasi k0n0, k0n1, k0n2, k0n3, dan k1n0, tetapi berbeda tidak nyata dibandingkan dengan kombinasi $\mathrm{k} 1 \mathrm{n} 1$, k2n0, dan k2n1. Kombinasi k1n1, k2n0, dan $\mathrm{k} 2 \mathrm{n} 1$ berbeda nyata dibandingkan dengan kombinasi k0n0, k0n1, k0n2, dan $\mathrm{k} 0 \mathrm{n} 3$, tetapi berbeda tidak nyata dibandingkan dengan kombinasi k1n0. Kombinasi $\mathrm{k} 1 \mathrm{n} 0$ berbeda nyata dibandingkan dengan kombinasi k0n3, tetapi berbeda tidak nyata dibandingkan dengan kombinasi k0n0, k0n1, dan k0n2. Kombinasi k0n1, k0n2 dan k0n3 berbeda nyata dibandingkan dengan kombinasi k0n0. Tanaman pakcoy paling tinggi pada umur 21 hari setelah tanam dhasilkan pada kombinasi $\mathrm{k} 3 \mathrm{n} 2$ yaitu $17,16 \mathrm{~cm}$, sedangkan yang paling rendah dihasilkan pada kombinasi k0n3 yaitu $12,72 \mathrm{~cm}$ (Tabel 3).

\subsection{Tinggi tanaman pada umur 28 hari setelah tanam}

Hasil sidik ragam menunjukkan bahwa perlakuan pupuk kandang kambing (K) dan POC Nasa (N) serta interaksinya $(\mathrm{K} \times \mathrm{N})$ berpengaruh sangat nyata terhadap tinggi tanaman pada umur 28 hari setelah tanam.

Hasil penelitian pengaruh pupuk kandang kambing (K) dan POC Nasa (N) serta interaksinya $(\mathrm{K} \times \mathrm{N})$ terhadap ratarata tinggi tanaman pakcoy pada umur 28 hari setelah tanam disajikan pada Tabel 4 .

Hasil uji BNT taraf 5\% pengaruh pupuk kandang kambing (K) terhadap rata-rata tinggi tanaman pakcoy pada umur 28 hari setelah tanam menunjukkan bahwa perlakuan $37,00 \mathrm{~g}^{\text {polibag }}{ }^{-1}(\mathrm{k} 1)$; $56,25 \mathrm{~g} \mathrm{polibag}^{-1}$ (k2); dan 75,00 $\mathrm{g}$ 
polibag $^{-1} \quad(\mathrm{k} 3)$ berbeda nyata dibandingkan dengan perlakuan tanpa pupuk kandang kambing (k0); dan diantara ketiga perlakuan (k1, k2, dan k3) tersebut juga berbeda nyata. Tanaman pakcoy paling tinggi pada umur 28 hari setelah tanam dhasilkan pada perlakuan $75,00 \mathrm{~g} \mathrm{polibag}^{-1}(\mathrm{k} 3)$ yaitu $20,86 \mathrm{~cm}$, sedangkan yang paling rendah dihasilkan pada perlakuan tanpa pupuk kandang kambing (k0) yaitu 16,79 cm (Tabel 4).

Tabel 4. Rata-rata Tinggi Tanaman Pakcoy pada Umur 28 Hari Setelah Tanam pada Berbagai Dosis Pupuk Kandang Kambing dan Konsentrasi POC Nasa serta Interaksinya (cm)

\begin{tabular}{lccccc}
\hline $\begin{array}{l}\text { Faktor Pupuk } \\
\text { Kandang Kambing } \\
(\mathrm{K})\end{array}$ & $\begin{array}{c}\text { Tanpa POC } \\
\text { Nasa (n0) }\end{array}$ & $\begin{array}{c}2 \mathrm{ml} \mathrm{l}^{-1} \text { air } \\
(\mathrm{n} 1)\end{array}$ & $\begin{array}{c}4 \mathrm{ml} \mathrm{l}^{-1} \text { air } \\
(\mathrm{n} 2)\end{array}$ & $6 \mathrm{ml} \mathrm{l}^{-1}$ air (n3) & $\begin{array}{c}\text { Rata-rata } \\
\text { Perlakuan } \\
(\mathrm{K}) *\end{array}$ \\
\hline $\begin{array}{l}\text { Tanpa } \\
\text { Pukan Kambing } \\
(\mathrm{k} 0)\end{array}$ & $16,80 \mathrm{e}$ & $16,62 \mathrm{e}$ & $17.06 \mathrm{e}$ & $16,78 \mathrm{e}$ & $16,79 \mathrm{~d}$ \\
$\begin{array}{l}37,00 \text { g polibag }^{-1} \\
(\mathrm{k} 1)\end{array}$ & $17,06 \mathrm{e}$ & $18,50 \mathrm{~d}$ & $19,44 \mathrm{c}$ & $19,00 \mathrm{c}$ & $18,50 \mathrm{c}$ \\
$\begin{array}{l}56,25 \text { g polibag }^{-1} \\
(\mathrm{k} 2)\end{array}$ & $18,48 \mathrm{~d}$ & $19,28 \mathrm{c}$ & $19,50 \mathrm{c}$ & $19,08 \mathrm{c}$ & $19,09 \mathrm{~b}$ \\
$\begin{array}{l}75,00 \text { g polibag }^{-1} \\
(\mathrm{k} 3)\end{array}$ & $19,14 \mathrm{c}$ & $20,60 \mathrm{~b}$ & $22,36 \mathrm{a}$ & $21,32 \mathrm{~b}$ & $20,86 \mathrm{a}$ \\
\hline $\begin{array}{l}\text { Rata-rata Perlakuan } \\
(\mathrm{N}) *\end{array}$ & $17,87 \mathrm{c}$ & $18,73 \mathrm{~b}$ & $19,59 \mathrm{a}$ & $19,05 \mathrm{~b}$ & \\
\hline
\end{tabular}

*) Angka rata-rata yang diikuti dengan huruf sama adalah berbeda tidak nyata berdasarkan hasil uji BNT taraf 5\%. (Nilai BNT K =0,47; BNT N =0,47, dan BNT KxN = 0,95).

Hasil uji BNT taraf 5\% pengaruh POC Nasa $(\mathrm{N})$ terhadap rata-rata tinggi tanaman pakcoy pada umur 28 hari setelah tanam menunjukkan bahwa $4 \mathrm{ml} \mathrm{l}^{-}$ 1 air (n2) berbeda nyata dibandingkan dengan perlakuan tanpa POC Nasa (n0); $2 \mathrm{ml} \mathrm{l}^{-1}$ air (n1); dan $6 \mathrm{ml} \mathrm{l}^{-1}$ air (n3). Perlakuan $2 \mathrm{ml} \mathrm{l}^{-1}$ air (n1) dan $6 \mathrm{ml} \mathrm{l}^{-1}$ air (n3) berbeda nyata dibandingkan dengan perlakuan tanpa POC Nasa (n0), tetapi diantara kedua perlakuan (n1 dan n3) tersebut berbeda tidak nyata. Tanaman pakcoy pakcoy paling tinggi pada umur 28 hari setelah tanam dhasilkan pada perlakuan $4 \mathrm{ml}^{-1}$ air (n3) yaitu $19,59 \mathrm{~cm}$, sedangkan yang paling rendah dihasilkan pada perlakuan tanpa POC Nasa (n0) yaitu 17,87 cm (Tabel 4).

Hasil uji BNT taraf 5\% pengaruh interaksi antara perlakuan pupuk kandang kambing dan POC Nasa $(\mathrm{KxN})$ terhadap rata-rata tinggi tanaman pakcoy pada umur 28 hari setelah tanam menunjukkan bahwa kombinasi $\mathrm{k} 3 \mathrm{n} 2$ berbeda nyata dibandingkan dengan kombinasi k0n0, $\mathrm{k} 0 \mathrm{n} 1, \mathrm{k} 0 \mathrm{n} 2, \mathrm{k} 0 \mathrm{n} 3, \mathrm{k} 1 \mathrm{n} 0, \mathrm{k} 1 \mathrm{n} 1, \mathrm{k} 1 \mathrm{n} 2$, $\mathrm{k} 1 \mathrm{n} 3, \mathrm{k} 2 \mathrm{n} 0, \mathrm{k} 2 \mathrm{n} 1, \mathrm{k} 2 \mathrm{n} 2, \mathrm{k} 2 \mathrm{n} 3, \mathrm{k} 3 \mathrm{n} 0$, $\mathrm{k} 3 \mathrm{n} 1$, dan $\mathrm{k} 3 \mathrm{n} 3$. Kombinasi k3n1 dan $\mathrm{k} 3 \mathrm{n} 3$ berbeda nyata dibandingkan dengan kombinasi k0n0, k0n1, k0n2, k0n3, k1n0, $\mathrm{k} 1 \mathrm{n} 1, \mathrm{k} 1 \mathrm{n} 2, \mathrm{k} 1 \mathrm{n} 3, \mathrm{k} 2 \mathrm{n} 0, \mathrm{k} 2 \mathrm{n} 1, \mathrm{k} 2 \mathrm{n} 2$, k2n3, dan k3n0. Kombinasi k1n2, k1n3, $\mathrm{k} 2 \mathrm{n} 1, \mathrm{k} 2 \mathrm{n} 2, \mathrm{k} 2 \mathrm{n} 3$ dan k3n0 berbeda nyata dibandingkan dengan kombinasi k0n0, k0n1, k0n2, k0n3, k1n0, k1n1, dan $\mathrm{k} 2 \mathrm{n} 0$. Kombinasi k1n1 dan $\mathrm{k} 2 \mathrm{n} 0$ berbeda nyata dibandingkan dengan kombinasi k0n0, k0n1, k0n2, k0n3, dan k1n0. Kombinasi k0n1, k0n2, k0n3, dan k1n0 berbeda tidak nyata dibandingkan dengan kombinasi k0n0. Tanaman pakcoy paling tinggi pada umur 28 hari setelah tanam dhasilkan pada kombinasi k3n2 yaitu $22,36 \mathrm{~cm}$, sedangkan yang paling rendah dihasilkan pada kombinasi k0n3 yaitu $16,78 \mathrm{~cm}$ (Tabel 4). 


\subsection{Jumlah daun pada umur 14 hari setelah tanam}

Hasil sidik ragam menunjukkan bahwa perlakuan pupuk kandang kambing (K) dan POC Nasa (N) berpengaruh sangat nyata; dan interaksinya berpengaruh nyata terhadap jumlah daun tanaman pakcoy pada umur 14 hari setelah tanam.

Hasil penelitian pengaruh pupuk kandang kambing $(\mathrm{K})$ dan POC Nasa $(\mathrm{N})$ serta interaksinya $(\mathrm{K} \mathrm{xN})$ terhadap ratarata jumlah daun tanaman pakcoy pada umur 14 hari setelah tanam disajikan pada Tabel 5.

Hasil uji BNT taraf 5\% pengaruh pupuk kandang kambing (K) terhadap rata-rata jumlah daun tanaman pakcoy pada umur 14 hari setelah tanam menunjukkan bahwa perlakuan $37,00 \mathrm{~g}$ polibag $^{-1}(\mathrm{k} 1)$; 56,25 g polibag $^{-1}$ (k2), dan $75,00 \mathrm{~g} \mathrm{polibag}^{-1}(\mathrm{k} 3)$ berbeda nyata dibandingkan dengan perlakuan tanpa pupuk kandang kambing (k0), dan diantara ketiga perlakuan (k1, k2, dan k3) tersebut juga berbeda nyata. Jumlah daun tanaman pakcoy paling banyak pada umur 14 hari setelah tanam dhasilkan pada perlakuan 75,00 $\mathrm{g}_{\text {polibag }}{ }^{-1}$ (k3) yaitu 9,40 helai, sedangkan yang paling sedikit dihasilkan pada perlakuan tanpa pupuk kandang kambing (k0) yaitu 5,50 helai (Tabel 5).

Tabel 5. Rata-rata Jumlah Daun Tanaman Pakcoy pada Umur 14 Hari Setelah Tanam pada Berbagai Dosis Pupuk Kandang Kambing dan Konsentrasi POC Nasa serta Interaksinya (helai)

\begin{tabular}{|c|c|c|c|c|c|}
\hline \multirow{2}{*}{$\begin{array}{l}\text { Faktor Pupuk } \\
\text { Kandang Kambing } \\
(\mathrm{K})\end{array}$} & \multicolumn{4}{|c|}{ Faktor POC Nasa $(\mathrm{N})$} & \multirow{2}{*}{$\begin{array}{l}\text { Rata-rata } \\
\text { Perlakuan } \\
(\mathrm{K})^{*}\end{array}$} \\
\hline & $\begin{array}{c}\text { Tanpa POC } \\
\text { Nasa }(\mathrm{n} 0)\end{array}$ & $\begin{array}{c}2 \mathrm{ml} \mathrm{l}^{-1} \text { air } \\
(\mathrm{n} 1)\end{array}$ & $\begin{array}{l}4 \mathrm{ml} \mathrm{l}^{-1} \text { air } \\
(\mathrm{n} 2)\end{array}$ & $6 \mathrm{ml} \mathrm{l}^{-1}$ air $(\mathrm{n} 3)$ & \\
\hline $\begin{array}{l}\text { Tanpa } \\
\text { Pukan Kambing (k0) }\end{array}$ & $5,20 \mathrm{~h}$ & $5,60 \mathrm{gh}$ & $5,60 \mathrm{gh}$ & $5,60 \mathrm{gh}$ & $5,50 \mathrm{~d}$ \\
\hline 37,00 g polibag $^{-1}(\mathrm{k} 1)$ & $6,00 \mathrm{~g}$ & $6,00 \mathrm{~g}$ & $7,00 \mathrm{f}$ & $7,60 \mathrm{e}$ & $6,65 \mathrm{c}$ \\
\hline $56,25 \mathrm{~g}$ polibag $^{-1}(\mathrm{k} 2)$ & $8,00 \mathrm{de}$ & $8,20 \mathrm{~cd}$ & $8,40 \mathrm{~cd}$ & $8,60 \mathrm{c}$ & $8,30 \mathrm{~b}$ \\
\hline 75,00 g polibag $^{-1}(\mathrm{k} 3)$ & $9,00 \mathrm{~b}$ & $9,40 \mathrm{ab}$ & $9,60 \mathrm{a}$ & $9,60 \mathrm{a}$ & $9,40 \mathrm{a}$ \\
\hline $\begin{array}{l}\text { Rata-rata Perlakuan } \\
(\mathrm{N}) *\end{array}$ & $7,05 \mathrm{~b}$ & $7,30 \mathrm{~b}$ & $7,65 \mathrm{a}$ & $7,85 \mathrm{a}$ & \\
\hline
\end{tabular}

*) Angka rata-rata yang diikuti dengan huruf sama adalah berbeda tidak nyata berdasarkan hasil uji BNT taraf 5\%. (Nilai BNT K =0,28; BNT $\mathrm{N}=0,28$, dan $\mathrm{BNT} \mathrm{KxN}=0,56$ ).

Hasil uji BNT taraf 5\% pengaruh POC Nasa $(\mathrm{N})$ terhadap rata-rata jumlah daun tanaman pakcoy pada umur 14 hari setelah tanam menunjukkan bahwa perlakuan $4 \mathrm{ml} \mathrm{l}^{-1}$ air (n2) dan $6 \mathrm{ml} \mathrm{l}^{-1}$ air (n3) berbeda nyata dibandingkan dengan perlakuan tanpa POC Nasa (n0) dan $2 \mathrm{ml}$ $\mathrm{l}^{-1}$ air (n1). Perlakuan $2 \mathrm{ml} \mathrm{l}^{-1}$ air (n1) berbeda tidak nyata dibandingkan dengan perlakuan tanpa POC Nasa (n0). Jumlah daun tanaman pakcoy paling banyak pada umur 14 hari setelah tanam dhasilkan pada perlakuan $6 \mathrm{ml} \mathrm{l}^{-1}$ air (n3) yaitu 7,85 helai, sedangkan yang paling sedikit dihasilkan pada perlakuan tanpa POC Nasa (n0) yaitu 7,05 helai (Tabel 5).

Hasil uji BNT taraf 5\% pengaruh interaksi antara perlakuan pupuk kandang kambing dan POC Nasa $(\mathrm{KxN})$ terhadap rata-rata jumlah daun tanaman pakcoy pada umur 14 hari setelah tanam menunjukkan bahwa kombinasi k3n2 dan $\mathrm{k} 3 \mathrm{n} 3$ berbeda nyata dibandingkan dengan kombinasi k0n0, k0n1, k0n2, k0n3, k1n0, $\mathrm{k} 1 \mathrm{n} 1, \mathrm{k} 1 \mathrm{n} 2, \mathrm{k} 1 \mathrm{n} 3, \mathrm{k} 2 \mathrm{n} 0, \mathrm{k} 2 \mathrm{n} 1, \mathrm{k} 2 \mathrm{n} 2$, $\mathrm{k} 2 \mathrm{n} 3, \mathrm{k} 3 \mathrm{n} 0$, tetapi berbeda tidak nyata dibandingkan dengan kombinasi $\mathrm{k} 3 \mathrm{n} 1$. Kombinasi k3n1 berbeda nyata 
dibandingkan dengan kombinasi k0n0, k0n1, k0n2, k0n3, k1n0, k1n1, k1n2, $\mathrm{k} 1 \mathrm{n} 3, \mathrm{k} 2 \mathrm{n} 0, \mathrm{k} 2 \mathrm{n} 1, \mathrm{k} 2 \mathrm{n} 2$, dan $\mathrm{k} 2 \mathrm{n} 3$, tetapi berbeda tidak nyata dibandingkan dengan kombinasi k3n0. Kombinasi k3n0 berbeda nyata dibandingkan dengan kombinasi k0n0, k0n1, k0n2, k0n3, k1n0, $\mathrm{k} 1 \mathrm{n} 1, \mathrm{k} 1 \mathrm{n} 2, \mathrm{k} 1 \mathrm{n} 3, \mathrm{k} 2 \mathrm{n} 0, \mathrm{k} 2 \mathrm{n} 1, \mathrm{k} 2 \mathrm{n} 2$, dan k2n3. Kombinasi k2n3 berbeda nyata dibandingkan dengan kombinasi k0n0, $\mathrm{k} 0 \mathrm{n} 1, \mathrm{k} 0 \mathrm{n} 2, \mathrm{k} 0 \mathrm{n} 3, \mathrm{k} 1 \mathrm{n} 0, \mathrm{k} 1 \mathrm{n} 1, \mathrm{k} 1 \mathrm{n} 2$, $\mathrm{k} 1 \mathrm{n} 3$, dan $\mathrm{k} 2 \mathrm{n} 0$, tetapi berbeda tidak nyata dibandingkan dengan kombinasi k2n1 dan k2n2. Kombinasi k2n1 dan $\mathrm{k} 2 \mathrm{n} 2$ berbeda nyata dibandingkan dengan kombinasi k0n0, k0n1, k0n2, k0n3, k1n0, $\mathrm{k} 1 \mathrm{n} 1, \mathrm{k} 1 \mathrm{n} 2$, dan $\mathrm{k} 1 \mathrm{n} 3$, tetapi berbeda tidak nyata dibandingkan dengan kombinasi k2n0. Kombinasi k2n0 berbeda nyata dibandingkan dengan kombinasi k0n0, k0n1, k0n2, k0n3, k1n0, $\mathrm{k} 1 \mathrm{n} 1$, dan $\mathrm{k} 1 \mathrm{n} 2$, tetapi berbeda tidak nyata dibandingkan dengan kombinasi k1n3. Kombinasi k1n3 berbeda nyata dibandingkan dengan kombinasi $\mathrm{k} 0 \mathrm{n} 0$, k0n1, k0n2, k0n3, k1n0, k1n1, dan k1n2. Kombinasi k1n2 berbeda nyata dibandingkan dengan kombinasi k0n0, k0n1, k0n2, k0n3, k1n0, dan k1n1.
Kombinasi k1n0 dan k1n1 berbeda nyata dibandingkan dengan kombinasi k0n0, tetapi berbeda tidak nyata dibandingkan dengan kombinasi k0n1, k0n2, dan k0n3. Kombinasi k0n1, k0n2, dan k0n3 berbeda tidak nyata dibandingkan dengan kombinasi k0n0. Jumlah daun tanaman pakcoy paling banyak pada umur 14 hari setelah tanam dhasilkan pada kombinasi k3n2 dan k3n3 yaitu 9,60 helai, sedangkan yang paling sedikit dihasilkan pada kombinasi k0n0 yaitu 5,20 helai (Tabel 5).

\subsection{Jumlah daun pada umur 21 hari setelah tanam}

Hasil sidik ragam menunjukkan bahwa perlakuan pupuk kandang kambing (K) dan POC Nasa (N) berpengaruh sangat nyata; dan interaksinya berpengaruh nyata terhadap jumlah daun tanaman pakcoy pada umur 21 hari setelah tanam.

Hasil penelitian pengaruh pupuk kandang kambing (K) dan POC Nasa (N) serta interaksinya $(\mathrm{K} \mathrm{xN})$ terhadap ratarata jumlah daun tanaman pakcoy pada umur 21 hari setelah tanam disajikan pada Tabel 6.

Tabel 6. Rata-rata Jumlah Daun Tanaman Pakcoy pada Umur 21 Hari Setelah Tanam pada Berbagai Dosis Pupuk Kandang Kambing dan Konsentrasi POC Nasa serta Interaksinya (helai)

\begin{tabular}{|c|c|c|c|c|c|}
\hline \multirow{2}{*}{$\begin{array}{l}\text { Faktor Pupuk } \\
\text { Kandang Kambing } \\
\text { (K) }\end{array}$} & \multicolumn{4}{|c|}{ Faktor POC Nasa (N) } & \multirow{2}{*}{$\begin{array}{c}\text { Rata-rata } \\
\text { Perlakuan } \\
(\mathrm{K})^{*}\end{array}$} \\
\hline & $\begin{array}{c}\text { Tanpa POC } \\
\text { Nasa }(\mathrm{n} 0)\end{array}$ & $\underset{(\mathrm{n} 1)}{2 \mathrm{ml} \mathrm{l}^{-1} \text { air }}$ & $\begin{array}{l}4 \mathrm{ml} \mathrm{l}^{-1} \text { air } \\
(\mathrm{n} 2)\end{array}$ & $6 \mathrm{ml} \mathrm{l}^{-1}$ air (n3) & \\
\hline $\begin{array}{l}\text { Tanpa } \\
\text { Pukan Kambing (k0) }\end{array}$ & $8,20 \mathrm{i}$ & $8,80 \mathrm{hi}$ & $8,80 \mathrm{hi}$ & $9,20 \mathrm{~h}$ & $8,75 \mathrm{~d}$ \\
\hline 37,00 g polibag $^{-1}(\mathrm{k} 1)$ & $10,00 \mathrm{~g}$ & $10,20 \mathrm{~g}$ & $10,60 \mathrm{fg}$ & $13,00 \mathrm{f}$ & $10,45 \mathrm{c}$ \\
\hline 56,25 g polibag $^{-1}(\mathrm{k} 2)$ & $11,80 \mathrm{e}$ & $12.40 \mathrm{e}$ & $13.40 \mathrm{~d}$ & $14.20 \mathrm{c}$ & $12,95 \mathrm{~b}$ \\
\hline $75,00 \mathrm{~g} \mathrm{polibag}^{-1}(\mathrm{k} 3)$ & $14,80 \mathrm{bc}$ & $15,00 \mathrm{ab}$ & $15,40 \mathrm{ab}$ & $15,60 \mathrm{a}$ & $15,20 \mathrm{a}$ \\
\hline $\begin{array}{l}\text { Rata-rata Perlakuan } \\
(\mathrm{N})^{*}\end{array}$ & $11,20 \mathrm{~d}$ & $11,60 \mathrm{c}$ & $12,05 \mathrm{~b}$ & $12,50 \mathrm{a}$ & \\
\hline
\end{tabular}

*) Angka rata-rata yang diikuti dengan huruf sama adalah berbeda tidak nyata berdasarkan hasil uji BNT taraf 5\%. (Nilai BNT K =0,31; BNT N =0,31; dan BNT KxN =0,62).

Hasil uji BNT taraf 5\% pengaruh pupuk kandang kambing (K) terhadap rata-rata jumlah daun tanaman pakcoy pada umur 21 hari setelah tanam menunjukkan bahwa perlakuan 37,00 g polibag $^{-1}(\mathrm{k} 1)$; 56,25 $\mathrm{g}$ polibag $^{-1}(\mathrm{k} 2)$, dan 
75,00 $\mathrm{g}_{\text {polibag }}{ }^{-1}$ (k3) berbeda nyata dibandingkan dengan perlakuan tanpa pupuk kandang kambing (k0), dan diantara ketiga perlakuan (k1, k2, dan k3) tersebut juga berbeda nyata. Jumlah daun tanaman pakcoy paling banyak pada umur 21 hari setelah tanam dhasilkan pada perlakuan $75,00 \mathrm{~g}_{\text {polibag }}{ }^{-1}(\mathrm{k} 3)$ yaitu 15,20 helai, sedangkan yang paling sedikit dihasilkan pada perlakuan tanpa pupuk kandang kambing (k0) yaitu 8,75 helai (Tabel 6).

Hasil uji BNT taraf 5\% pengaruh POC Nasa $(\mathrm{N})$ terhadap rata-rata jumlah daun tanaman pakcoy pada umur 21 hari setelah tanam menunjukkan bahwa perlakuan $2 \mathrm{ml} \mathrm{l}^{-1}$ air (n1), $4 \mathrm{ml} \mathrm{l}^{-1}$ air (n2), dan $6 \mathrm{ml} \mathrm{l}^{-1}$ air (n3) berbeda nyata dibandingkan dengan perlakuan tanpa POC Nasa (n0), dan diantara ketiga perlakuan (n1, n2, dan n3) tersebut juga berbeda nyata. Jumlah daun tanaman pakcoy paling banyak pada umur 21 hari setelah tanam dhasilkan pada perlakuan 6 $\mathrm{ml} \mathrm{l}^{-1}$ air (n3) yaitu 12,50 helai, sedangkan yang paling sedikit dihasilkan pada perlakuan tanpa POC Nasa (n0) yaitu 11,20 helai (Tabel 6).

Hasil uji BNT taraf 5\% pengaruh interaksi antara perlakuan pupuk kandang kambing dan POC Nasa $(\mathrm{KxN})$ terhadap rata-rata jumlah daun tanaman pakcoy pada umur 21 hari setelah tanam menunjukkan bahwa kombinasi k3n3 berbeda nyata dibandingkan dengan kombinasi k0n0, k0n1, k0n2, k0n3, k1n0, $\mathrm{k} 1 \mathrm{n} 1, \mathrm{k} 1 \mathrm{n} 2, \mathrm{k} 1 \mathrm{n} 3, \mathrm{k} 2 \mathrm{n} 0, \mathrm{k} 2 \mathrm{n} 1, \mathrm{k} 2 \mathrm{n} 2$, $\mathrm{k} 2 \mathrm{n} 3, \mathrm{k} 3 \mathrm{n} 0$, tetapi berbeda tidak nyata dibandingkan dengan kombinasi $\mathrm{k} 3 \mathrm{n} 1$ dan k3n2. Kombinasi k3n1 dan k3n2 berbeda nyata dibandingkan dengan kombinasi k0n0, k0n1, k0n2, k0n3, k1n0, $\mathrm{k} 1 \mathrm{n} 1, \mathrm{k} 1 \mathrm{n} 2, \mathrm{k} 1 \mathrm{n} 3, \mathrm{k} 2 \mathrm{n} 0, \mathrm{k} 2 \mathrm{n} 1, \mathrm{k} 2 \mathrm{n} 2$, dan $\mathrm{k} 2 \mathrm{n} 3$, tetapi berbeda tidak nyata dibandingkan dengan kombinasi k3n0. Kombinasi k3n0 berbeda nyata dibandingkan dengan kombinasi k0n0, k0n1, k0n2, k0n3, k1n0, k1n1, k1n2, $\mathrm{k} 1 \mathrm{n} 3, \mathrm{k} 2 \mathrm{n} 0, \mathrm{k} 2 \mathrm{n} 1$, dan $\mathrm{k} 2 \mathrm{n} 2$, tetapi berbeda tidak nyata dibandingkan dengan kombinasi k2n3. Kombinasi k2n3 berbeda nyata dibandingkan dengan kombinasi k0n0, k0n1, k0n2, k0n3, k1n0, $\mathrm{k} 1 \mathrm{n} 1, \mathrm{k} 1 \mathrm{n} 2, \mathrm{k} 1 \mathrm{n} 3, \mathrm{k} 2 \mathrm{n} 0, \mathrm{k} 2 \mathrm{n} 1$ dan k2n2. Kombinasi k2n2 berbeda nyata dibandingkan dengan kombinasi $\mathrm{k} 0 \mathrm{n} 0$, k0n1, k0n2, k0n3, k1n0, k1n1, k1n2, k1n3, k2n0 dan k2n1. Kombinasi k2n0 dan $\mathrm{k} 2 \mathrm{n} 1$ berbeda nyata dibandingkan dengan kombinasi k0n0, k0n1, k0n2, k0n3, k1n0, k1n1, k1n2, dan k1n3. Kombinasi k1n3 berbeda nyata dibandingkan dengan kombinasi k0n0, k0n1, k0n2, k0n3, k1n0, dan k1n1, tetapi berbeda tidak nyata dibandingkan dengan kombinasi k1n2. Kombinasi k1n2 berbeda nyata dibandingkan dengan kombinasi k0n0, k0n1, k0n2, dan k0n3, tetapi berbeda tidak nyata dibandingkan dengan kombinasi k1n0 dan k1n1. Kombinasi k1n0 dan k1n1 berbeda nyata dibandingkan dengan kombinasi k0n0, k0n1, k0n2, dan k0n3. Kombinasi k0n3 berbeda nyata dibandingkan dengan kombinasi k0n0, tetapi berbeda tidak nyata dibandingkan dengan kombinasi k0n1 dan k0n2. Kombinasi k0n1 dan k0n2 berbeda tidak nyata dibandingkan dengan kombinasi k0n0. Jumlah daun tanaman pakcoy paling banyak pada umur 21 hari setelah tanam dhasilkan pada kombinasi k3n3 yaitu 15,60 helai, sedangkan yang paling sedikit dihasilkan pada kombinasi k0n0 yaitu 8,20 helai (Tabel 6).

\subsection{Jumlah daun pada umur 28 hari setelah tanam}

Hasil sidik ragam menunjukkan bahwa perlakuan pupuk kandang kambing (K) dan POC Nasa (N) serta interaksinya berpengaruh sangat nyata terhadap jumlah daun tanaman pakcoy pada umur 28 hari setelah tanam.

Hasil penelitian pengaruh pupuk kandang kambing (K) dan POC Nasa (N) 
serta interaksinya $(\mathrm{K} \times \mathrm{N})$ terhadap ratarata jumlah daun tanaman pakcoy pada umur 28 hari setelah tanam disajikan pada Tabel 7.

Tabel 7. Rata-rata Jumlah Daun Tanaman Pakcoy pada Umur 28 Hari Setelah Tanam pada Berbagai Dosis Pupuk Kandang Kambing dan Konsentrasi POC Nasa serta Interaksinya (helai)

\begin{tabular}{lccccc}
\hline $\begin{array}{l}\text { Faktor Pupuk Kandang } \\
\text { Kambing (K) }\end{array}$ & $\begin{array}{c}\text { Tanpa } \\
\text { POC Nasa } \\
(\mathrm{n} 0)\end{array}$ & $\begin{array}{c}2 \mathrm{ml} \mathrm{l}^{-1} \text { air } \\
(\mathrm{n} 1)\end{array}$ & $\begin{array}{c}4 \mathrm{ml} \mathrm{l}^{-1} \text { air } \\
(\mathrm{n} 2)\end{array}$ & $6 \mathrm{ml} \mathrm{l}^{-1}$ air (n3) & $\begin{array}{c}\text { Rata-rata } \\
\text { Perlakuan } \\
(\mathrm{K}) *\end{array}$ \\
\hline $\begin{array}{l}\text { Tanpa } \\
\text { Pukan Kambing (k0) }\end{array}$ & $10,20 \mathrm{i}$ & $10,80 \mathrm{i}$ & $11,00 \mathrm{i}$ & $12,40 \mathrm{~h}$ & $11,10 \mathrm{~d}$ \\
37,00 g polibag $^{-1}(\mathrm{k} 1)$ & $14,40 \mathrm{~g}$ & $15,00 \mathrm{fg}$ & $15,80 \mathrm{ef}$ & $15,80 \mathrm{ef}$ & $15,25 \mathrm{c}$ \\
56,25 g polibag $^{-1}(\mathrm{k} 2)$ & $16,40 \mathrm{e}$ & $18,00 \mathrm{~d}$ & $18,00 \mathrm{~d}$ & $19,80 \mathrm{c}$ & $18,05 \mathrm{~b}$ \\
75,00 g polibag $^{-1}(\mathrm{k} 3)$ & $19,00 \mathrm{c}$ & $21,20 \mathrm{~b}$ & $22,60 \mathrm{a}$ & $23,40 \mathrm{a}$ & $21,55 \mathrm{a}$ \\
\hline $\begin{array}{l}\text { Rata-rata Perlakuan } \\
(\mathrm{N}) *\end{array}$ & $15,00 \mathrm{~d}$ & $16,25 \mathrm{c}$ & $16,85 \mathrm{~b}$ & $17,85 \mathrm{a}$ & \\
\hline
\end{tabular}

*) Angka rata-rata yang diikuti dengan huruf sama adalah berbeda tidak nyata berdasarkan hasil uji BNT taraf 5\%. (Nilai BNT K =0,45; BNT N =0,45; dan BNT KxN=0,91).

Hasil uji BNT taraf 5\% pengaruh pupuk kandang kambing (K) terhadap rata-rata jumlah daun tanaman pakcoy pada umur 28 hari setelah tanam menunjukkan bahwa perlakuan $37,00 \mathrm{~g}$ polibag $^{-1}(\mathrm{k} 1) ; 56,25 \mathrm{~g}_{\text {polibag }}{ }^{-1}(\mathrm{k} 2)$, dan $75,00 \mathrm{~g} \mathrm{polibag}^{-1}(\mathrm{k} 3)$ berbeda nyata dibandingkan dengan perlakuan tanpa pupuk kandang kambing (k0), dan diantara ketiga perlakuan $(\mathrm{k} 1, \mathrm{k} 2$, dan $\mathrm{k} 3)$ tersebut juga berbeda nyata. Jumlah daun tanaman pakcoy paling banyak pada umur 28 hari setelah tanam dhasilkan pada perlakuan $75,00 \mathrm{~g}_{\text {polibag }}{ }^{-1}$ (k3) yaitu 21,55 helai, sedangkan yang paling sedikit dihasilkan pada perlakuan tanpa pupuk kandang kambing (k0) yaitu 11,10 helai (Tabel 7).

Hasil uji BNT taraf 5\% pengaruh POC Nasa $(\mathrm{N})$ terhadap rata-rata jumlah daun tanaman pakcoy pada umur 28 hari setelah tanam menunjukkan bahwa perlakuan $2 \mathrm{ml} \mathrm{l}^{-1}$ air (n1), $4 \mathrm{ml} \mathrm{l}^{-1}$ air (n2), dan $6 \mathrm{ml} \mathrm{l}^{-1}$ air (n3) berbeda nyata dibandingkan dengan perlakuan tanpa POC Nasa (n0), dan diantara ketiga perlakuan (n1, n2, dan n3) tersebut juga berbeda nyata. Jumlah daun tanaman pakcoy paling banyak pada umur 28 hari setelah tanam dhasilkan pada perlakuan 6 $\mathrm{ml} \mathrm{1}^{-1}$ air (n3) yaitu 17,85 helai, sedangkan yang paling sedikit dihasilkan pada perlakuan tanpa POC Nasa (n0) yaitu 15,00 helai (Tabel 7).

Hasil uji BNT taraf 5\% pengaruh interaksi antara perlakuan pupuk kandang kambing dan POC Nasa $(\mathrm{KxN})$ terhadap rata-rata jumlah daun tanaman pakcoy pada umur 28 hari setelah tanam menunjukkan bahwa kombinasi k3n2 dan $\mathrm{k} 3 \mathrm{n} 3$ berbeda nyata dibandingkan dengan kombinasi k0n0, k0n1, k0n2, k0n3, k1n0, $\mathrm{k} 1 \mathrm{n} 1, \mathrm{k} 1 \mathrm{n} 2, \mathrm{k} 1 \mathrm{n} 3, \mathrm{k} 2 \mathrm{n} 0, \mathrm{k} 2 \mathrm{n} 1, \mathrm{k} 2 \mathrm{n} 2$, $\mathrm{k} 2 \mathrm{n} 3, \mathrm{k} 3 \mathrm{n} 0$, dan k3n1. Kombinasi k3n1 berbeda nyata dibandingkan dengan kombinasi k0n0, k0n1, k0n2, k0n3, k1n0, $\mathrm{k} 1 \mathrm{n} 1, \mathrm{k} 1 \mathrm{n} 2, \mathrm{k} 1 \mathrm{n} 3, \mathrm{k} 2 \mathrm{n} 0, \mathrm{k} 2 \mathrm{n} 1, \mathrm{k} 2 \mathrm{n} 2$, dan $\mathrm{k} 2 \mathrm{n} 3$. Kombinasi k2n3 dan k3n0 berbeda nyata dibandingkan dengan kombinasi k0n0, k0n1, k0n2, k0n3, k1n0, k1n1, $\mathrm{k} 1 \mathrm{n} 2, \mathrm{k} 1 \mathrm{n} 3, \mathrm{k} 2 \mathrm{n} 0, \mathrm{k} 2 \mathrm{n} 1$, dan k2n2. Kombinasi k2n1 dan k2n2 berbeda nyata dibandingkan dengan kombinasi k0n0, $\mathrm{k} 0 \mathrm{n} 1, \mathrm{k} 0 \mathrm{n} 2, \mathrm{k} 0 \mathrm{n} 3, \mathrm{k} 1 \mathrm{n} 0, \mathrm{k} 1 \mathrm{n} 1, \mathrm{k} 1 \mathrm{n} 2$, k1n3, dan k2n0. Kombinasi k2n0 berbeda nyata dibandingkan dengan kombinasi k0n0, k0n1, k0n2, k0n3, k1n0, $\mathrm{k} 1 \mathrm{n} 1$, tetapi berbeda tidak nyata 
dibandingkan dengan $\mathrm{k} 1 \mathrm{n} 2$ dan $\mathrm{k} 1 \mathrm{n} 3$. Kombinasi k1n2 dan k1n3 berbeda nyata dibandingkan dengan kombinasi k0n0, $\mathrm{k} 0 \mathrm{n} 1, \mathrm{k} 0 \mathrm{n} 2, \mathrm{k} 0 \mathrm{n} 3$, dan $\mathrm{k} 1 \mathrm{n} 0$, tetapi berbeda tidak nyata dibandingkan dengan k1n0. Kombinasi k1n0 berbeda nyata dibandingkan dengan kombinasi k0n0, k0n1, k0n2, dan k0n3. Kombinasi k0n3 berbeda nyata dibandingkan dengan kombinasi k0n0, k0n1, dan k0n2. Kombinasi k0n1 dan k0n2 berbeda tidak nyata dibandingkan dengan kombinasi k0n0. Jumlah daun tanaman pakcoy paling banyak pada umur 28 hari setelah tanam dhasilkan pada kombinasi k3n3 yaitu 23,40 helai, sedangkan yang paling sedikit dihasilkan pada kombinasi k0n0 yaitu 10,20 helai (Tabel 7).

\subsection{Produksi Tanaman}

Hasil sidik ragam menunjukkan bahwa perlakuan pupuk kandang kambing (K) dan POC Nasa (N) serta interaksinya $(\mathrm{K} \times \mathrm{N})$ berpengaruh sangat nyata terhadap produksi tanaman pakcoy.

Hasil penelitian pengaruh pupuk kandang kambing (K) dan POC Nasa (N) serta interaksinya $(\mathrm{K} \times \mathrm{N})$ terhadap ratarata produksi tanaman pakcoy disajikan pada Tabel 8.

Tabel 8. Rata-rata Produksi Tanaman Pakcoy pada Berbagai Dosis Pupuk Kandang Kambing dan Konsentrasi POC Nasa serta Interaksinya $\left(\mathrm{g}_{\text {tanaman }}{ }^{-1}\right)$

\begin{tabular}{lccccc}
\hline $\begin{array}{l}\text { Faktor Pupuk } \\
\text { Kandang Kambing } \\
(\mathrm{K})\end{array}$ & $\begin{array}{c}\text { Tanpa POC } \\
\text { Nasa }(\mathrm{n} 0)\end{array}$ & $\begin{array}{c}2 \mathrm{ml} \mathrm{l} \text {-1 air } \\
(\mathrm{n} 1)\end{array}$ & $\begin{array}{c}4 \mathrm{ml} \mathrm{l}^{-1} \text { air } \\
(\mathrm{n} 2)\end{array}$ & $6 \mathrm{ml} \mathrm{l}^{-1}$ air $(\mathrm{n} 3)$ & $\begin{array}{c}\text { Rata-rata } \\
\text { Perlakuan } \\
(\mathrm{K}) *\end{array}$ \\
\hline $\begin{array}{l}\text { Tanpa } \\
\text { Pukan Kambing }(\mathrm{k} 0)\end{array}$ & $26,60 \mathrm{l}$ & $28,40 \mathrm{kl}$ & $39,00 \mathrm{k}$ & $51,20 \mathrm{j}$ & $36,30 \mathrm{~d}$ \\
$\begin{array}{l}37,00 \mathrm{~g} \mathrm{polibag}^{-1}(\mathrm{k} 1) \\
56,25 \mathrm{~g} \mathrm{polibag}^{-1}(\mathrm{k} 2)\end{array}$ & $68,40 \mathrm{i}$ & $71,20 \mathrm{hi}$ & $82,20 \mathrm{gh}$ & $89,80 \mathrm{fg}$ & $77,90 \mathrm{c}$ \\
75,00 g polibag $^{-1}(\mathrm{k} 3)$ & $100,00 \mathrm{f}$ & $113,80 \mathrm{e}$ & $132,60 \mathrm{~d}$ & $154,60 \mathrm{c}$ & $125,25 \mathrm{~b}$ \\
\hline $\begin{array}{l}\text { Rata-rata Perlakuan } \\
(\mathrm{N}) *\end{array}$ & $91,70 \mathrm{~d}$ & $97,45 \mathrm{c}$ & $108,15 \mathrm{~b}$ & $119,30 \mathrm{a}$ & $177,15 \mathrm{a}$ \\
\hline
\end{tabular}

*) Angka rata-rata yang diikuti dengan huruf sama adalah berbeda tidak nyata berdasarkan hasil uji BNT taraf 5\%. (Nilai BNT K =5,61; BNT N = 5,61; dan BNT KxN = 11,30).

Hasil uji BNT taraf 5\% pengaruh pupuk kandang kambing (K) terhadap rata-rata produksi tanaman pakcoy menunjukkan bahwa perlakuan $37,00 \mathrm{~g}$ polibag $^{-1}(\mathrm{k} 1)$; 56,25 g polibag $^{-1}$ (k2), dan $75,00 \mathrm{~g} \mathrm{polibag}^{-1}(\mathrm{k} 3)$ berbeda nyata dibandingkan dengan perlakuan tanpa pupuk kandang kambing (k0), dan diantara ketiga perlakuan $(\mathrm{k} 1, \mathrm{k} 2$, dan $\mathrm{k} 3)$ tersebut juga berbeda nyata. Produksi tanaman pakcoy paling tinggi dhasilkan pada perlakuan $75,00 \mathrm{~g}$ polibag $^{-1}(\mathrm{k} 3)$ yaitu $177,15 \mathrm{~g} \mathrm{tanaman}{ }^{-1}$, sedangkan yang paling rendah dihasilkan pada perlakuan tanpa pupuk kandang kambing (k0) yaitu 36,30 g tanaman ${ }^{-1}$ (Tabel 8).
Hasil uji BNT taraf 5\% pengaruh POC Nasa (N) terhadap rata-rata produksi tanaman pakcoy menunjukkan bahwa perlakuan $2 \mathrm{ml} \mathrm{l}^{-1}$ air (n1). $4 \mathrm{ml} \mathrm{l}^{-1}$ air (n2), dan $6 \mathrm{ml} \mathrm{l}^{-1}$ air (n3) berbeda nyata dibandingkan dengan perlakuan tanpa POC Nasa (n0) dan diantara ketiga perlakuan (n1, n2, dan n3) tersebut juga berbeda nyata. Produksi tanaman pakcoy paling tinggi dihasilkan pada perlakuan $6 \mathrm{ml} \mathrm{l}^{-1}$ air (n3) yaitu 119,30 g tanaman $^{-1}$, sedangkan yang paling rendah dihasilkan pada perlakuan tanpa POC Nasa (n0) yaitu 91,70 g tanaman ${ }^{-1}$ (Tabel 8).

Hasil uji BNT taraf 5\% pengaruh interaksi antara perlakuan pupuk kandang 
kambing dan POC Nasa $(\mathrm{KxN})$ terhadap rata-rata produksi tanaman pakcoy menunjukkan bahwa kombinasi k3n3 berbeda nyata dibandingkan dengan kombinasi k0n0, k0n1, k0n2, k0n3, k1n0, $\mathrm{k} 1 \mathrm{n} 1, \mathrm{k} 1 \mathrm{n} 2, \mathrm{k} 1 \mathrm{n} 3, \mathrm{k} 2 \mathrm{n} 0, \mathrm{k} 2 \mathrm{n} 1, \mathrm{k} 2 \mathrm{n} 2$, $\mathrm{k} 2 \mathrm{n} 3, \mathrm{k} 3 \mathrm{n} 0, \mathrm{k} 3 \mathrm{n} 1$, dan $\mathrm{k} 3 \mathrm{n} 2$. Kombinasi $\mathrm{k} 3 \mathrm{n} 0$, k3n1 dan $\mathrm{k} 3 \mathrm{n} 2$ berbeda nyata dibandingkan dengan kombinasi k0n0, $\mathrm{k} 0 \mathrm{n} 1, \mathrm{k} 0 \mathrm{n} 2, \mathrm{k} 0 \mathrm{n} 3, \mathrm{k} 1 \mathrm{n} 0, \mathrm{k} 1 \mathrm{n} 1, \mathrm{k} 1 \mathrm{n} 2$, $\mathrm{k} 1 \mathrm{n} 3, \mathrm{k} 2 \mathrm{n} 0, \mathrm{k} 2 \mathrm{n} 1$, dan k2n2. Kombinasi $\mathrm{k} 2 \mathrm{n} 3$ berbeda nyata dibandingkan dengan kombinasi k0n0, k0n1, k0n2, k0n3, k1n0, $\mathrm{k} 1 \mathrm{n} 1, \mathrm{k} 1 \mathrm{n} 2, \mathrm{k} 1 \mathrm{n} 3, \mathrm{k} 2 \mathrm{n} 0, \mathrm{k} 2 \mathrm{n} 1$, dan k2n2. Kombinasi k2n2 berbeda nyata dibandingkan dengan kombinasi k0n0, k0n1, k0n2, k0n3, k1n0, k1n1, k1n2, $\mathrm{k} 1 \mathrm{n} 3, \mathrm{k} 2 \mathrm{n} 0$, dan k2n1. Kombinasi k2n1 berbeda nyata dibandingkan dengan kombinasi k0n0, k0n1, k0n2, k0n3, k1n0, $\mathrm{k} 1 \mathrm{n} 1, \mathrm{k} 1 \mathrm{n} 2, \mathrm{k} 1 \mathrm{n} 3$, dan k2n0. Kombinasi $\mathrm{k} 2 \mathrm{n} 0$ berbeda nyata dibandingkan dengan kombinasi k0n0, k0n1, k0n2, k0n3, k1n0, $\mathrm{k} 1 \mathrm{n} 1$, dan $\mathrm{k} 1 \mathrm{n} 2$, tetapi berbeda tidak nyata dibandingkan dengan kombinasi k1n3. Kombinasi k1n3 berbeda nyata dibandingkan dengan kombinasi k0n0, k0n1, k0n2, k0n3, k1n0, dan k1n1, tetapi berbeda tidak nyata dibandingkan dengan kombinasi k1n2. Kombinasi k1n2 berbeda nyata dibandingkan dengan kombinasi k0n0, k0n1, k0n2, k0n3, dan $\mathrm{k} 1 \mathrm{n} 0$, tetapi berbeda tidak nyata dibandingkan dengan kombinasi k1n1. Kombinasi k1n1 berbeda nyata dibandingkan dengan kombinasi k0n0, $\mathrm{k} 0 \mathrm{n} 1$, k0n2, dan k0n3, tetapi berbeda tidak nyata dibandingkan dengan kombinasi k1n0.

Kombinasi k1n0 berbeda nyata dibandingkan dengan kombinasi k0n0, k0n1, k0n2, dan k0n3. Kombinasi k0n3 berbeda nyata dibandingkan dengan kombinasi k0n0, k0n1, dan k0n2. Kombinasi k0n2 berbeda nyata dibandingkan dengan kombinasi k0n0, tetapi berbeda tidak nyata dibandingkan dengan kombinasi k0n1. Kombinasi k0n1 berbeda tidak nyata dibandingkan dengan kombinasi k0n0. Produksi tanaman pakcoy paling tinggi dihasilkan pada kombinasi k3n3yaitu 181,60 g tanaman $^{-1}$, sedangkan yang paling rendah dihasilkan pada kombinasi k0n0 yaitu 26,60 g tanaman ${ }^{-1}$ (Tabel 8).

Hasil sidik ragam menunjukkan bahwa perlakuan pupuk kandang kambing berpengaruh sangat nyata terhadap tinggi tanaman dan jumlah daun tanaman pakcoy pada umur 14, 21 dan 28 hari setelah tanam. Hasil penelitian yang disajikan pada Tabel 10 menunjukkan bahwa tanaman pakcoy yang paling rendah dan jumlah daun paling sedikit dihasilkan pada perlakuan tanpa pupuk kandang kambing. Keadaan ini disebabkan karena media tanam yang digunakan memiliki kandungan unsur hara bahan organik dan unsur hara $\mathrm{N}$ yang tergolong rendah dan kapasitas tukar kation yang tergolong sedang, sehingga tanaman pakcoy tidak dapat tumbuh dengan baik. Hal ini didukung oleh hasil analisis di laboratorium menunjukkan bahwa media tanam mengandung $0,12 \% \mathrm{~N}$ total (rendah); $1,36 \%$ C-organik (rendah); $\mathrm{pH}$ tanah $=$ 6,20 (agak masam); dan nilai KTK = 19,64 miliekuivalen $100^{-1} \mathrm{~g}$ tanah (sedang).

Hasil penelitian juga menunjukkan bahwa pemberian berbagai dosis pupuk kandang kambing yaitu 37,00 g polibag $^{-1}$ (k1); 56,25 g polibag $^{-1}(\mathrm{k} 2)$, dan 75,00 g polibag $^{-1}$ (k3) menghasilkan tanaman pakcoy yang lebih tinggi dan jumlah daun pada umur 14, 21 dan 28 hari setelah tanam yang lebih banyak dibandingkan dengan perlakuan tanpa pupuk kandang kambing (k0). Hal ini disebabkan dengan pemberian pupuk kandang kambing dapat meningkatkan ketersediaan unsur hara terutama unsur hara $\mathrm{N}$ yang sangat dibutuhkan untuk pertumbuhan vegetatif tanaman. Seperti dinyatakan oleh Lingga dan Marsono 
(2003) bahwa unsur hara $\mathrm{N}$ berperan untuk memacu pertumbuhan vegetatif tanaman,

Hasil sidik ragam menunjukkan bahwa perlakuan pupuk kandang kambing berpengaruh sangat nyata terhadap produksi tanaman pakcoy. Hasil penelitian yang disajikan pada Tabel 10 menunjukkan bahwa pemberian berbagai dosis pupuk kandang kambing yaitu $37,00 \mathrm{~g}$ polibag $^{-1}(\mathrm{k} 1) ; 56,25 \mathrm{~g}$ polibag $^{-1}(\mathrm{k} 2)$, dan 75,00 g polibag $^{-1}(\mathrm{k} 3)$ menghasilkan produksi tanaman pakcoy yang lebih tinggi dibandingkan tanpa pupuk kandang kambing (k0). Produksi tanaman pakcoy paling tinggi dihasilkan pada perlakuan $75,00 \mathrm{~g}_{\text {polibag }}{ }^{-1}(\mathrm{k} 3)$ yaitu $177,15 \mathrm{~g}$ polibag $^{-1}$, sedangkan yang paling rendah dihasilkan pada perlakuan tanpa pupuk kandang kambing ( $\mathrm{k} 0)$ yaitu $36,30 \mathrm{~g}$ polibag $^{-1}$. Keadaan ini berkaitan erat dengan makin baiknya pertumbuhan tinggi tanaman dan jumlah daun yang dihasilkan dan akan diikuti dengan meningkatnya produksi tanaman. Hal ini disebabkan dengan pemberian pupuk kandang kambing, maka unsur hara makro dan unsur hara mikro yang dibutuhkan oleh tanaman dapat terpenuhi, selain itu juga adanya perbaikan sifat fisik tanah dan sifat biologis tanah, sehingga tanaman pakcoy dapat tumbuh dengan baik dan memberikan produksi yang tinggi. Menurut Musnawar (2003) bahwa manfaat pemberian pupuk organik padat seperti pupuk kandang kambing adalah dapat menambah kesuburan tanaman, memperbaiki sifat kimia, biologi dan fisik tanah serta tidak mencemari lingkungan.

Hasil sidik ragam menunjukkan bahwa perlakuan POC Nasa berpengaruh sangat nyata terhadap tinggi tanaman dan jumlah daun tanaman pakcoy pada umur 14, 21, dan 28 hari setelah tanam. Hasil penelitian yang disajikan pada Tabel 10 menunjukkan bahwa perlakuan tanpa pemberian POC Nasa (n0) menghasilkan tinggi tanaman pakcoy yang paling rendah dan jumlah daun paling sedikit. Keadaan ini disebabkan karena kandungan unur hara $\mathrm{N}$ dalam media tanam hanya sebesar $0,12 \% \mathrm{~N}$ total (tergolong rendah) dan juga kandungan 1,36\% C-organik (tergolong rendah); tanah bereaksi agak masam $(\mathrm{pH}$ tanah $=$ 6,20) serta nilai KTK $=19,64$ miliekuivalen $100^{-1} \mathrm{~g}$ tanah (tergolong sedang). Keadaan ini menyebabkan media tanam tidak dapat menyediakan unsur hara yang cukup untuk mendukung pertumbuhan tinggi dan jumlah daun tanaman pakcoy.

Hasil penelitian menunjukkkan bahwa pemberian berbagai konsentrasi POC Nasa yaitu $2 \mathrm{ml} \mathrm{l}^{-1}$ air (n1), $4 \mathrm{ml} \mathrm{l}^{-1}$ air (n2), dan $6 \quad \mathrm{ml}^{-1}$ air (n3) menghasilkan pertumbuhan tanaman yang lebih tinggi dan jumlah daun tanaman pakcoy yang lebih banyak. Pertumbuhan tanaman yang paling tinggi dan jumlah daun paling banyak dihasilkan pada perlakuan $6 \mathrm{ml} \mathrm{l}^{-1}$ air (n3). Hal ini disebabkan dengan pemberian berbagai konsentrasi POC Nasa dapat meningkatkan serapan unsur hara makro dan mikro oleh tanaman, sehingga tanaman dapat tumbuh dengan baik dan menghasilkan pertumbuhan vegetatif yang lebih baik.

Pada pengamatan produksi tanaman pakcoy menunjukkan bahwa perlakuan POC Nasa berpengaruh sangat nyata. Hasil penelitian menunjukkan bahwa pemberian berbagai konsentrasi POC Nasa yaitu $2 \mathrm{ml} \mathrm{l}^{-1}$ air (n1), $4 \mathrm{ml} \mathrm{l}^{-1}$ air (n2), dan $6 \mathrm{ml} \mathrm{l}^{-1}$ air (n3) menghasilkan produksi tanaman pakcoy yang lebih tinggi dibandingkan dengan perlakuan tanpa POC Nasa (n0). Produksi tanaman pakcoy paling tinggi dihasilkan pada perlakuan $6 \mathrm{ml} \mathrm{l}^{-1}$ air (n3) yaitu 119,30 g polibag $^{-1}$, disusul perlakuan $4 \mathrm{ml} \mathrm{l}^{-1}$ air (n2) yaitu $108,15 \mathrm{~g}_{\text {polibag }}{ }^{-1}$ dan $2 \mathrm{ml} \mathrm{l}^{-1}$ air (n1) yaitu 97,45 $\mathrm{g}$ polibag $^{-1}$ sedangkan produksi yang terendah dihasilkan pada 
perlakuan tanpa POC Nasa (n0) yaitu $91,70 \mathrm{~g} \mathrm{polibag}^{-1}$. Tingginya produksi tanaman pakcoy yang dihasilkan tersebut berkaitan erat dengan makin baiknya pertumbuhan tinggi dan jumlah daun tanaman pakcoy yang dihasilkan. Hal ini disebabkan dengan pemberian berbagai konsentrasi POC Nasa dapat mencukupi kebutuhan unsur hara makro dan mikro tanaman, maka tanaman dapat tumbuh dan memberikan hasil yang baik. Menurut Pardono (2014) bahwa POC Nasa mengandung unsur hara makro dan mikro yaitu antara lain : $\mathrm{N} 0,06 \% ; \mathrm{P}_{2} \mathrm{O}_{5}$ $0,01 \% ; \mathrm{K}_{2} \mathrm{O} 0,11 \%$; C Organik 4,53\%; Zn 37,8\% ppm; Cu 6,45 ppm; Mn 2,38 ppm; Co 2,13 ppm; Fe 0,43 ppm; S 0,1\%; $\mathrm{Ca} 61,04$ ppm; Mg 14,53 ppm; $\mathrm{Cl} 0,26 \%$; Na 0,13 ppm; B 42, 49 ppm; Si 0,01\%; Al 6,38 ppm; $\mathrm{NaCl} 0,98 \%$; Se 0,11 ppm; $\mathrm{Cr}<0,05 \mathrm{ppm} ; \mathrm{Mo}<0,2 \mathrm{ppm} ; \mathrm{V}<0,04$ ppm; $\mathrm{So}_{4}$ 0,31\%; pH 7,9; Disamping itu juga dilengkapi dengan lemak $0,39 \%$; protein $0,38 \%$; humat 0,01 ; Vulvat; ZPT (Giberilin, Sitokinin, Auksin), bebas logam berat $(\mathrm{Pb}, \mathrm{Cd}, \mathrm{Hg}, \mathrm{As})$ dan bebas mikroba $E$ coli, dan Salmonelia. Menurut Lingga dan Marsono (2008), agar pemberian pupuk daun memberikan hasil sesuai dengan yang diharapkan, maka konsentrasi yang diberikan tidak melebihi konsentrasi yang dianjurkan.

Hasil sidik ragam menunjukkan bahwa interaksi antara faktor dosis pupuk kandang kambing dan faktor konsentrasi POC Nasa berpengaruh nyata sampai berpengaruh sangat nyata terhadap tinggi tanaman dan jumlah daun pada umur 14, 21, dan 28 hari setelah tanam dan produksi tanaman pakcoy. Keadaan ini menunjukkan bahwa antara faktor dosis pupuk kandang kambing dan faktor konsentrasi POC Nasa secara bersama-sama ataupun tidak secara bersama-sama dalam mempengaruhi pertumbuhan dan hasil tanaman pakcoy. Menurut Gomez dan Gomez (1995), bahwa dua faktor dikatakan berinteraksi apabila pengaruh suatu faktor perlakuan berubah pada saat perubahan taraf faktor perlakuan lainnya. Selanjutnya dinyatakan oleh Steel dan Torrie (1991), bahwa apabila pengaruh interaksi berbeda nyata maka disimpulkan bahwa diantara faktor perlakuan tersebut bertindak tidak bebas satu sama lainnya (pengaruhnya secara bersama-sama).

Secara umum hasil penelitian menunjukkan bahwa perlakuan kombinasi antara berbagai dosis pupuk kandang kambing dan berbagai konsentrasi POC Nasa menghasilkan pertumbuhan tanaman yang lebih tinggi, jumlah daun yang lebih banyak, dan produksi tanaman pakcoy yang lebih tinggi dibandingkan dengan kombinasi tanpa pupuk kandang kambing dan tanpa POC Nasa $(\mathrm{k} 0 \mathrm{n} 0)$. Produksi tanaman pakcoy paling tinggi dihasilkan pada perlakuan kombinasi k2n3 yaitu 181, 60 $\mathrm{g}^{-1}$ polibag, sedangkan produksi tanaman yang paling rendah dihasilkan pada perlakuan kombinasi $\mathrm{k} 0 \mathrm{n} 0$ yaitu $26,60 \mathrm{~g}^{-1}$ polibag. Hal ini disebabkan dengan pemberian pupuk kandang kambing yang dikombinasikan dengan POC Nasa dapat menyediakan unsur hara baik makro maupun mikro, sehingga tanaman pakcoy dapat tumbuh baik dan memberikan hasil yang tinggi. Menurut Prihmantoro (1999) bahwa sebaiknya unsur hara makro dan mikro diberikan secara rutin agar tanaman dapat tumbuh dengan baik. Unsur-unsur hara tersebut dapat diberikan bersama baik melalui akar maupun melalui daun. Selanjutnya dinyatakan oleh Dwidjoseputro (1998), bahwa tanaman akan tumbuh subur dan memberikan hasil yang baik jika unsur hara yang dibutuhkannya tersedia dalam jumlah cukup dan seimbang.

\section{KESIMPULAN}

Berdasarkan hasil penelitian dan pembahasan dapat disimpulkan yaitu 
sebagai berikut : Perlakuan pupuk kandang kambing berpengaruh sangat nyata terhadap tinggi tanaman dan jumlah daun pada umur 14,21 , dan 28 hari setelah tanam, dan produksi tanaman pakcoy.

Perlakuan POC Nasa berpengaruh sangat nyata terhadap tinggi tanaman dan jumlah daun pada umur 14, 21, dan 28 hari setelah tanam, dan produksi tanaman pakcoy.

Perlakuan interaksi antara pupuk kandang kambing dan POC Nasa berpengaruh nyata sampai berpengaruh sangat nyata terhadap tinggi tanaman dan jumlah daun pada umur 14, 21, dan 28 hari setelah tanam, dan produksi tanaman pakcoy.

Produksi tanaman pakcoy yang paling tinggi dihasilkan pada perlakuan kombinasi 75,00 $\mathrm{g}^{-1}$ polibag pupuk kandang kambing dan $6 \mathrm{ml} \mathrm{l}^{-1}$ air POC Nasa (k3n3) yaitu $181,60 \mathrm{~g}^{-1}$ polibag, sedangkan yang paling rendah dihasilkan pada kombinasi tanpa pupuk kandang kambing dan tanpa POC Nasa (k0n0) yaitu $26,60 \mathrm{~g}^{-1}$ polibag.

\section{DAFTAR PUSTAKA}

Dewi, S.S, Bambang H.I, Dewi P. (2013). Pengaruh Macam Pupuk Organik terhadap Pertumbuhan dan Hasil Jagung Manis (Zea mays saccharata, Sturt). Jurnal Agrosains. Vol 1 No 1 ISSN 0216499X.

Dinas Peternakan Provinsi Jawa Timur. (2011). Statistik Produksi Ternak Jawa Timur. Diakses 14 Mei 2012, dari

http://disnak.jatimprov.go.id/web/st atistik_produksi_detail.php.

Dwidjoseputro, D. (1998) . Pengantar Fisiologi Tumbuhan . Jakarta: Gramedia.
Edi, S. dan Bobihoe, J. (2010). Budidaya

Tanaman Sayur. Balai Pengkajian

Teknologi Pertanian (BPTP), Jambi.

Gomez, K.A. dan A.A. Gomez. (1995). Preosedur Statistika untuk

Penelitian Pertanian (Terjemahan Endang Syamsuddin dan J.S. Baharsjah). Jakarta: UI Press.

Haryanto. (2007). Teknik Budidaya Sayuran Pakcoy (Sawi Mangkok). Jakarta: Penebar Swadaya.

Lingga, P. dan Marsono. (2008). Petunjuk Penggunaan Pupuk. Jakarta: Penebar Swadaya.

Musnamar, E. I. (2003). Pupuk Organik Padat: Pembuatan dan Aplikasinya. Jakarta: Penebar Swadaya.

Prihmantoro, H. (1999). Memupuk Tanaman Sayur. Jakarta: Penebar Swadaya.

Sukmawati, S. (2012). Budidaya pakcoy (Brassica chinensis. L) Secara Organik dengan Pengaruh Beberapa Jenis Pupuk Organik. Lampung: Politeknik Negeri Lampung.

Steel, R.G.D dan J. H. Torrie. (1991). Prinsip dan Prosedur Statistika Suatu Pendekatan Biometrik. Jakarta: Gramedia Pustaka Utama.

Sugito, Y., Yulia W,. Dan Ellis W. (1995). Sistem Pertanian Organik. Malang: Fakultas Pertanian Universitas Brawijaya Malang.

Yitnosumarto, Suntoyo. (1993). Percobaan : Perencanaan, Analisis, dan Interpretasinya. Jakarta: PT. Gramedia Pustaka Utama. 